\title{
Mineralogy and geochemistry of banded iron formation and iron ores from eastern India with implications on their genesis
}

\author{
Subrata RoY ${ }^{1, *}$ and A S VenKatesh ${ }^{2}$ \\ ${ }^{1}$ MNP Division, National Metallurgical Laboratory, Jamshedpur, India. \\ ${ }^{2}$ Department of Applied Geology, Indian School of Mines University, Dhanbad, India. \\ *e-mail: roy.subrata11@yahoo.com
}

The geological complexities of banded iron formation (BIF) and associated iron ores of JillingLangalata iron ore deposits, Singhbhum-North Orissa Craton, belonging to Iron Ore Group (IOG) eastern India have been studied in detail along with the geochemical evaluation of different iron ores. The geochemical and mineralogical characterization suggests that the massive, hard laminated, soft laminated ore and blue dust had a genetic lineage from BIFs aided with certain input from hydrothermal activity. The PAAS normalized REE pattern of Jilling BIF striking positive Eu anomaly, resembling those of modern hydrothermal solutions from mid-oceanic ridge (MOR). Major part of the iron could have been added to the bottom sea water by hydrothermal solutions derived from hydrothermally active anoxic marine environments. The ubiquitous presence of intercalated tuffaceous shales indicates the volcanic signature in BIF.

Mineralogical studies reveal that magnetite was the principal iron oxide mineral, whose depositional history is preserved in BHJ, where it remains in the form of martite and the platy hematite is mainly the product of martite. The different types of iron ores are intricately related with the BHJ. Removal of silica from BIF and successive precipitation of iron by hydrothermal fluids of possible meteoric origin resulted in the formation of martite-goethite ore. The hard laminated ore has been formed in the second phase of supergene processes, where the deep burial upgrades the hydrous iron oxides to hematite. The massive ore is syngenetic in origin with BHJ. Soft laminated ores and biscuity ores were formed where further precipitation of iron was partial or absent.

\section{Introduction}

Banded iron formation (BIF) represents one of the most distinctive rock types that occur widespread in space and time in the earlier part of the Precambrian in most of the shield areas of the world. The huge iron ore deposits of JharkhandOrissa region, eastern India (figure 1a) are part of the volcano-sedimentary basins containing iron and to some extent manganese deposits of Precambrian age (Jones 1934). Various workers from time to time studied on different aspects of BIF and iron ores of eastern India (Jones 1934; Dunn
1935; Banerji 1977; Chakraborty and Majumder 2002). The structure and tectonic aspects of the BIF were studied by Saha et al (1984). Most of these banded iron-formation horizons belong to the oxide facies banded iron-formations as defined by Chakraborty and Majumder (2002), but silicate facies banded iron-formations are also locally developed (Bhattacharya et al 2007).

Studies on various aspects of BIFs and the resultant iron ores especially the high grade hematitic ores are attracting the attention of different researchers in recent times. Beukes and Gutzmer (2008) stressed the importance of facies

Keywords. Banded iron formation; hematite; blue dust; mineralogical characterization; archean iron ore group; India. 


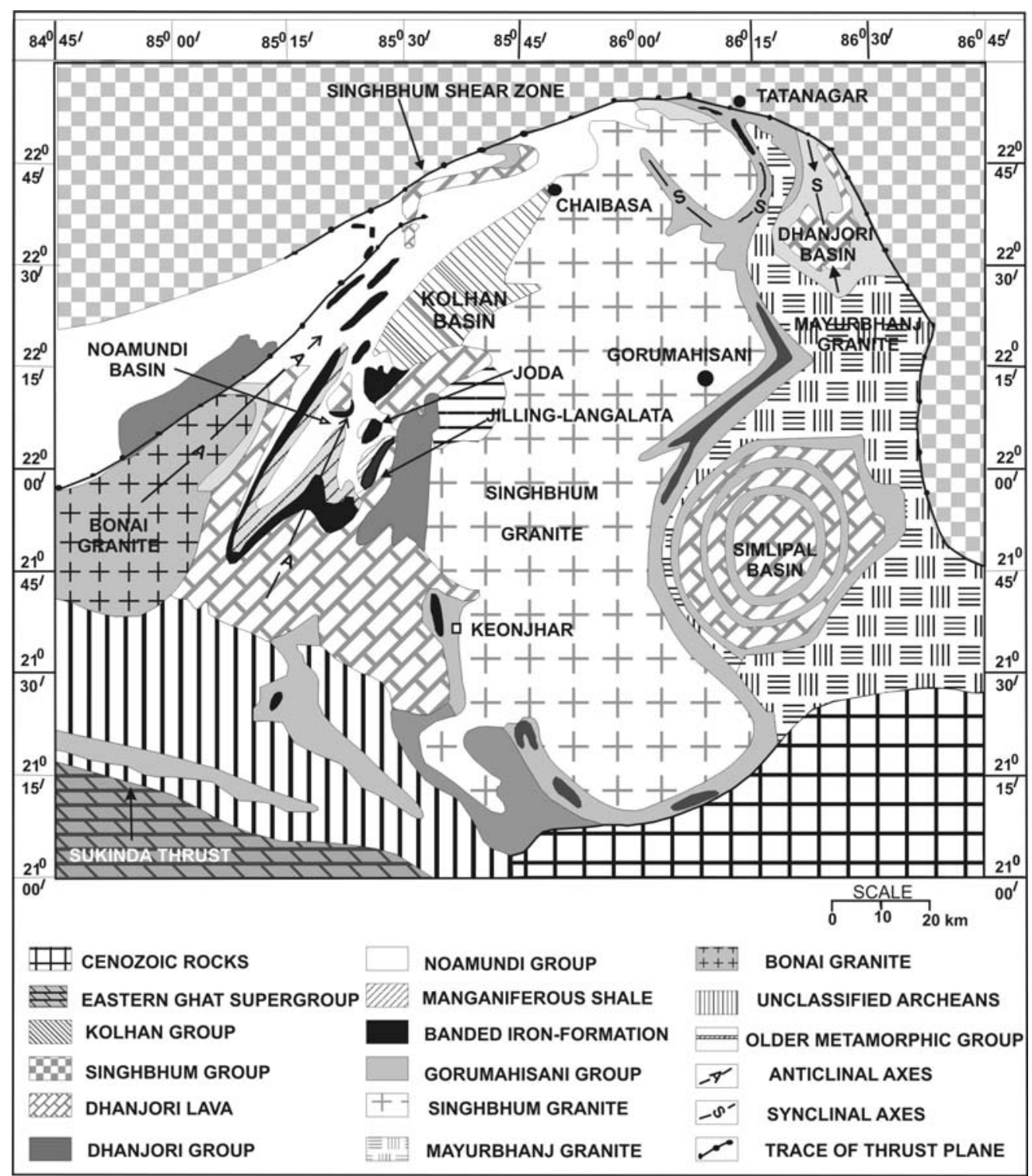

(a)

Figure 1(a). Geological map of iron ore deposits of eastern India (modified after Chakraborty and Majumder 1986). (Jilling-Langalata iron ore deposits are located at the eastern limb of the synclinorium).

architecture in formulating genetic models of iron ores and especially noted that such studies from Brazilian and Indian iron ores are missing. Dalstra and Roserie (2008) also opine that the iron ores hosted by Archean BIF are little understood and in such deposits structures play a major role in the preservation of these deposits by providing a link between a source of hydrothermal, silica-undersaturated fluids and iron formation or allowed the meteoric waters to control the sites of iron ore formation in the BIF.

The Precambrian iron ore of Singhbhum-North Orissa region of eastern India occurs as part of the horse-shoe shaped broad synclinorium known as Iron Ore Group (IOG) of rocks that host most important iron ore deposits of India (figure 1a).
Structural analysis in the eastern anticline of the horse-shoe synclinorium suggests that the BIF hosting the high grade iron ore bodies are disposed in three linear NNE-SSW trending belts and the major iron ore deposits in the eastern anticline at the present level of erosion are preferentially localized within shallow basinal structures only (Ghosh and Mukhopadhyay 2007). The Jilling-Langalata iron ore deposit forms a part of the eastern limb of the north plunging asymmetric 'horse-shoe shaped synclinorium' (figure 1a). The iron ore deposits of economic importance occur in close association with BIF in Jilling-Langalata mining areas.

The genesis of these high-grade hematite ores remains controversial while such studies incorporating genetic models on high-grade iron ores 


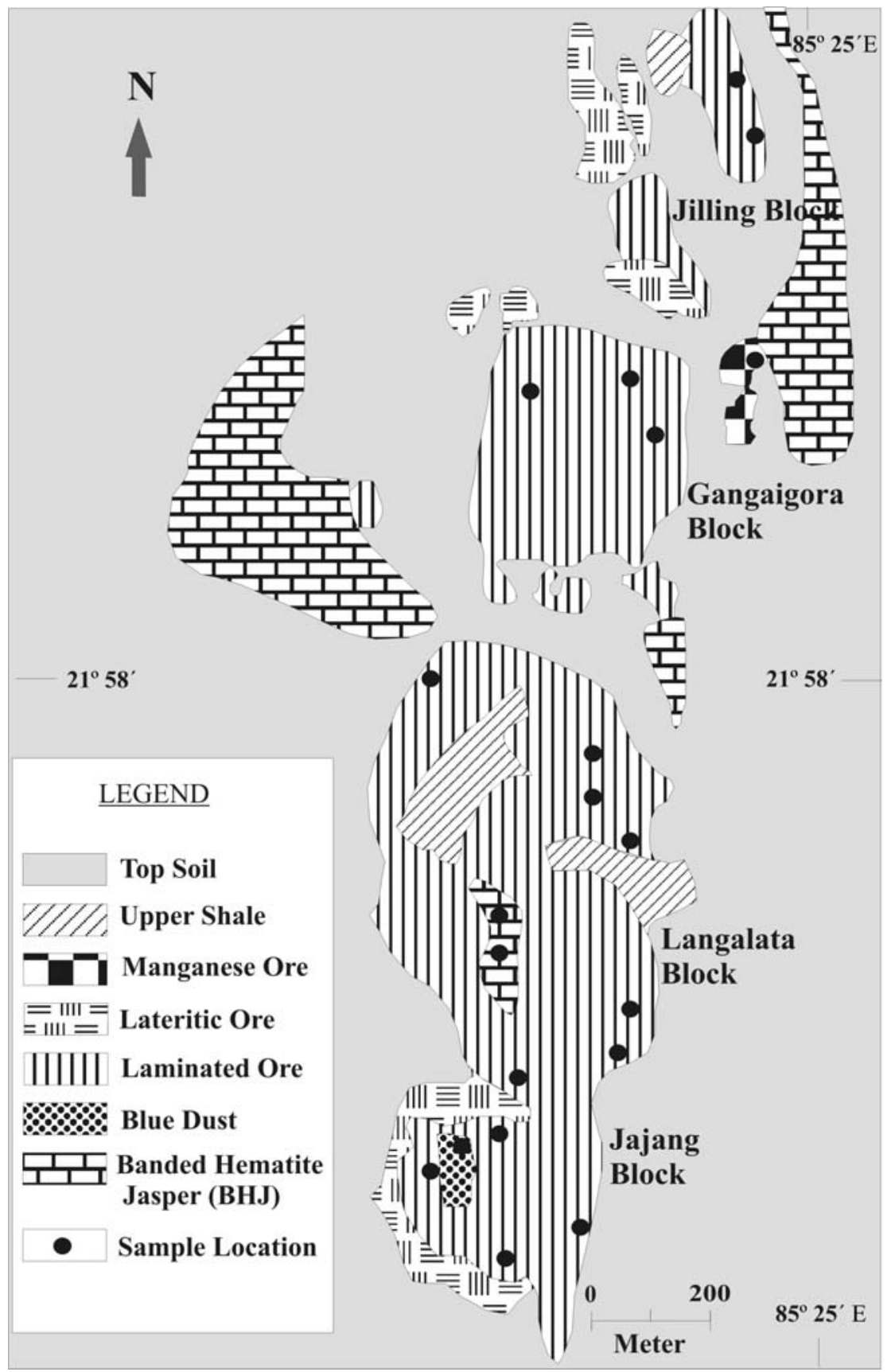

(b)

Figure 1(b). Geological map of Jilling-Langalata iron ore deposits showing distribution of different ore types and sample locations.

have been postulated by various workers elsewhere. They include deep-seated hydrothermal, syngenetic and diagenetic (Taylor et al 2001). Supergene enrichment followed by metamorphism is the most widely cited explanation for the genesis of high-grade hematite ores in Hamersley province (Morris 1985; Harmsworth et al 1990 and Thorne et al 2008). However, certain workers expressed reservations over this supergene model (Findlay 1994; Martin et al 1998; Barley et al 1999; Oliver and Dickens 1999; Powell et al 1999 and Taylor et al 2001).

The genetic aspects and diagenetic features on eastern Indian ores have been initially studied by Banerji (1977); Majumder (1985); Gross (1993) and Chakraborty and Majumder (2002). The chemical and mineralogical variations between banded iron formations and high-grade massive including blue dust varieties from this region and the implications for their origin from BIF to iron 
ore still remain unresolved. Controversies about the origin of banded hematite and high-grade ores appear largely due to the monomineralic composition of the ores.

Here, we partly fill this critical gap by documenting and presenting our views based on the mineralogy and geochemistry of the banded hematite jasper (BHJ) and high-grade ores as well as different types of iron ores from JillingLangalata iron ore deposits. The geochemical results of the banded iron ore are used to delineate the genesis of different ore types, the redox conditions of the sea bottom water and source of the Fe and other elements in these banded iron-formations as well as the genesis of high-grade ores.

\section{Geology of the Jilling-Langalata iron ore deposits}

Jilling-Langalata area belongs to SinghbhumOrissa Iron Ore Craton (SOIOC) contains vast deposits of iron ore known as IOG (Saha 1994).

The Precambrian IOG largely contains BIF in addition to the other volcano-sedimentary rocks ( 3.1-3.3 Ga, Sarkar et al 1969), forming a significant portion of the Singhbhum-North Orissa Craton of eastern Indian shield (Saha et al 1984). The weakly metamorphosed volcano-sedimentary sequence of rocks, occurring in and around the area, belongs to the iron ore series of Precambrian age (Jones 1934) and forms part of the eastern limb exhibiting a westerly dip of the northerly plunging asymmetric synclinorium. The IOG in addition to BIF also contains other rock units like two generations of shales, tuffs that underlie or are interlayered with BIF.

High-grade hematite ore is concentrated in tabular stratabound bodies hosted by the BIF. Several economically significant ore bodies are located in the Jilling-Langalata deposits occurring over a $10 \mathrm{~km}$ distance. These are, from north to south, known as the Jilling, Gangaigora, Langalata and Jajang block. High-grade iron ores occur in three distinct stratigraphic positions above the BIF. Massive and hard laminated ore bodies constitute the bulk of the ore resource and are particularly well developed towards the Southern Range; they are irregular, tabular in shape, range in thickness between 2 and $50 \mathrm{~m}$ and occur just above the BHJ. Among the deposits, Langalata are the biggest, consisting $73 \%$ of the total bulk of the ore deposit (figure 1b). The ore bodies have thickness ranging from $2.20 \mathrm{~m}$ to $66.7 \mathrm{~m}$ up to a maximum depth of $76.90 \mathrm{~m}$ and the total reserves of Jilling-Langalata deposits is 61.7 million tonnes. Since multiple generations of shales occur rhythemically as markers within the IOG, the possibility of iron ore below the BHJ cannot be ruled out.

\subsection{Shale units}

Occurrence of two distinct shale formations in IOG of rocks have been reported by Sarangi and Acharya (1975) and Murthy and Acharya (1975). On the basis of their field occurrence and subsurface information, they are divisible in to three broad units in Jilling-Langalata such as lower shale, parting or middle shale and upper shale.

The lower shale formation overlies the tuffaceous rock and lava and the lower shale physically resembles the underlying tuffaceous rock and the lava and tuffaceous rock gradually weather towards the top up to the base of BIF. The parting shale or middle occur as thin partings/lensoid shape within the iron ore and is not restricted to any particular stratigraphic horizon which has a limited exposure expressing inter-beded relationship with the iron ore (figure $2 \mathrm{a}$ ). The upper shale is generally friable in nature often laminated, rich in silt sized sediments and exhibits considerable thickness towards west of Langalata Pahar in the valley portion (figure $2 \mathrm{~b}$ ).

\subsection{Banded hematite jasper}

BHJ in Jilling-Langalata exhibits convolute bedding and peni-contemporaneous structures at places and is unevenly banded with the thickness of individual band varies from a few $\mathrm{mm}$ to $5 \mathrm{~cm}$. It is seen to pass in to massive ore and further passes into laminated ore/lenses or pockets of powdery ore as seen in Langalata block (figure 3).

\subsection{Iron ore}

Strartigraphically, BHJ is overlain by iron ore but exposures at most of the places show that the iron ore body particularly massive ore body directly rest on the lower shale. The general trend of iron ore in Jilling-Langalata deposit is N-S exhibiting rolling dips with prominent vertical joints.

Ore textures in BIF derived ores are complex due to deformation, mild alteration, supergene processes and secondary mineral formation. Some of the microstructural and textural features that were observed in these areas include microfolds, brecciated zones, microfaults and microbands. The iron ores have been classified as banded hematite jasper, massive ore, hard laminated ore, soft laminated ore, martite-goethite ore, flaky friable ore (biscuity), blue dust and lateritic ore on the basis of detailed mineralogical characterization including SEM study. 

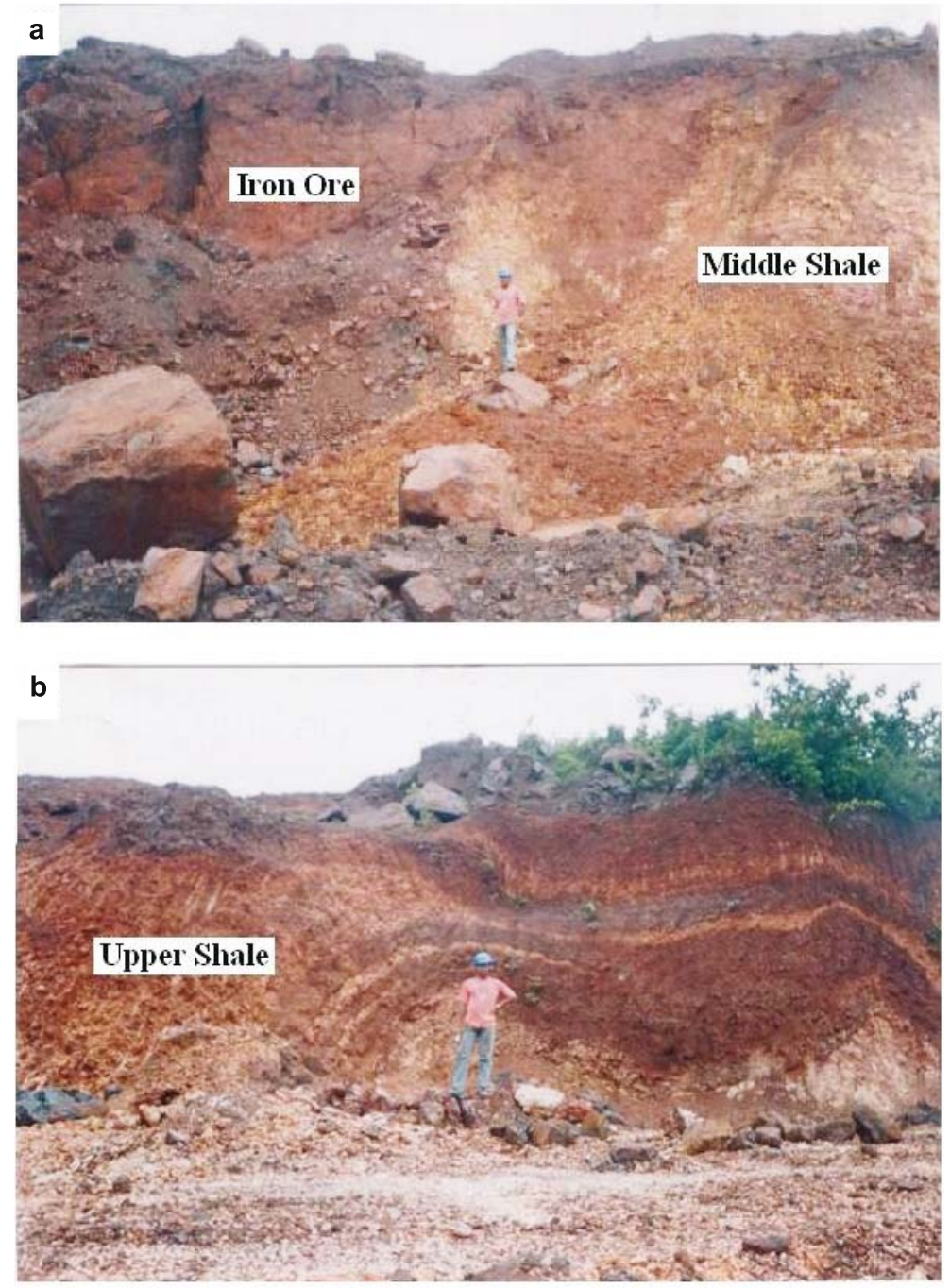

Figure 2. A closer view of quarry face in Jilling-Langalata iron ore mines showing occurrence of middle shale and upper shale.

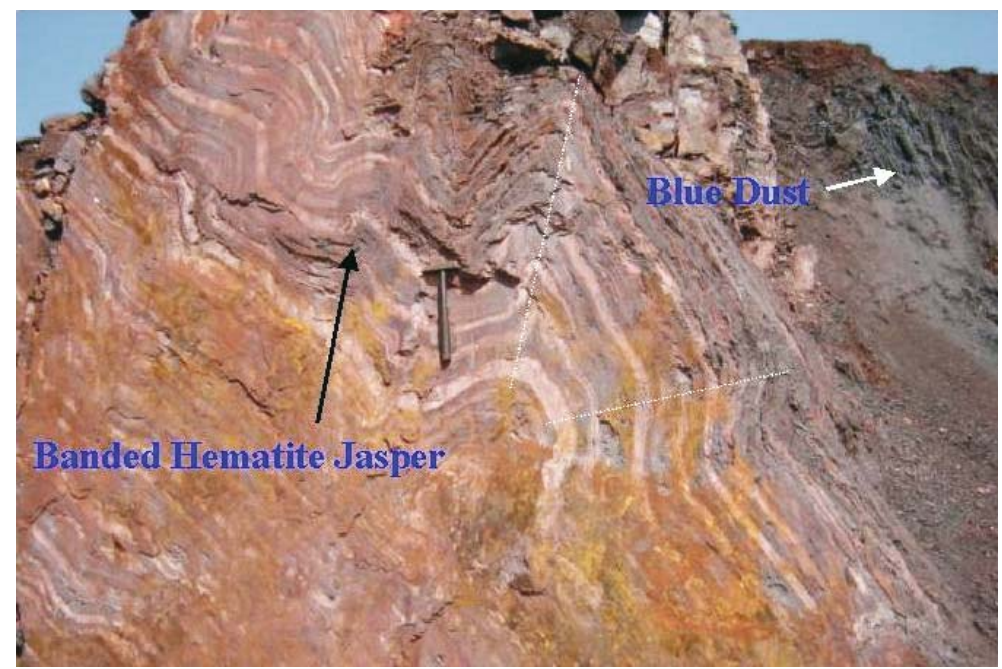

Figure 3. A closer view of quarry face in Jilling-Langalata iron ore mines showing occurrence of blue dust in contact with banded hematite jasper. 


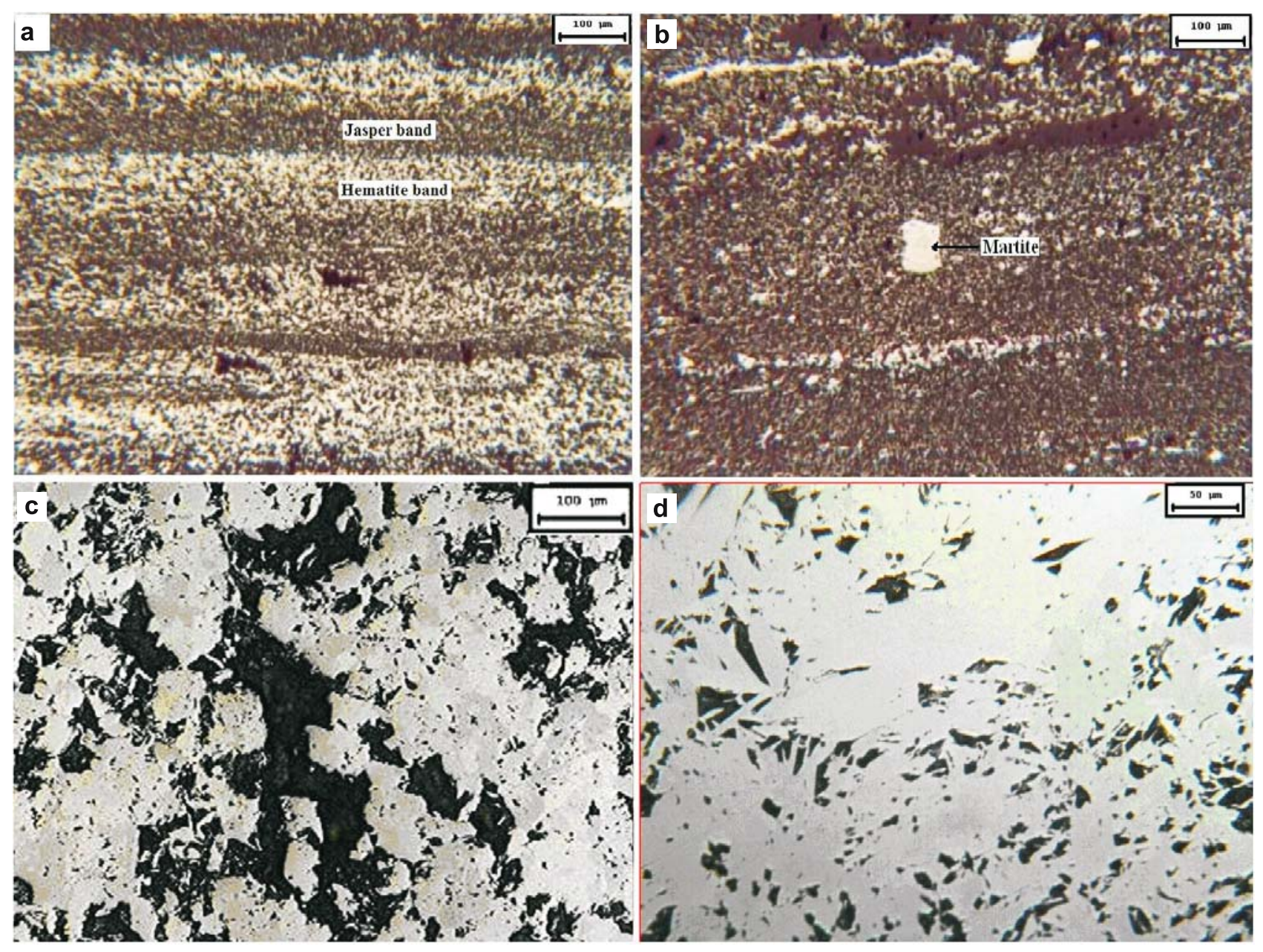

Figure 4. Photomicrographs of iron ore samples under reflected light microscope, (a) alternate bands of hematite and jasper in banded hematite jasper, (b) martite in banded hematite jasper, (c) martite in massive iron ore, and (d) fine-to-medium grained micro-platy hematite grains are intricately associated with each other leaving very fine inter-granular micro-pore spaces in massive ore.

\section{Sampling and methodology}

Samples were collected from several continuous outcrops of the Jilling-Langalata iron ore deposits on the basis of variations in different types of ore (figure 1b). Iron ore samples representing banded hematite jasper, massive ore, hard laminated ore, soft laminated ore, martite-goethite ore, blue dust, flaky-friable ore and lateritic ores along with three types of shales were collected from fresh exposures and mine faces from Jilling-Langalata iron ore deposits. Channel samples covering all types of ores were collected from different mining benches of the active mining pits and random grab samples were collected from the exposures in Jajang, Langalata, Gangaigora and Jilling blocks.

Various types of ore specimens were cut into smaller sizes by diamond wheel saw (Carl-Zeiss) and Isocut slow speed saw (Buhler-make) and thin-polish sections of different samples were prepared. Detailed ore microscopic studies have been conducted to study the mineralogy, texture, microstructural aspects in respect to various ore types. For SEM study, sample $(5 \times 5 \times 5 \mathrm{~mm}$ size $)$ was first coated with ultra thin film of carbon by an ion sputtered JFC-1100 and then exposed under JEOL, JSM-35CF electron microscope at National Metallurgical Laboratory (NML), Jamshedpur. For this, the working height was kept at $15 \mathrm{~mm}$ with voltage ranging between $10-25 \mathrm{kV}$. Backscattered images were obtained to delineate the various mineral phases. The detailed microscopic and mineral chemical studies using XRD, SEMEDS revealed the presence of various iron mineral phases, nature of iron and gangue minerals and their specific textural variations.

Samples were crushed and pulverized to -200 micron size for chemical analysis. Representative samples were analyzed for major element analysis using XRF spectrometry. The trace and rare earth elements (REE) were analyzed at National Geophysical Research Institute (NGRI), Hyderabad, 

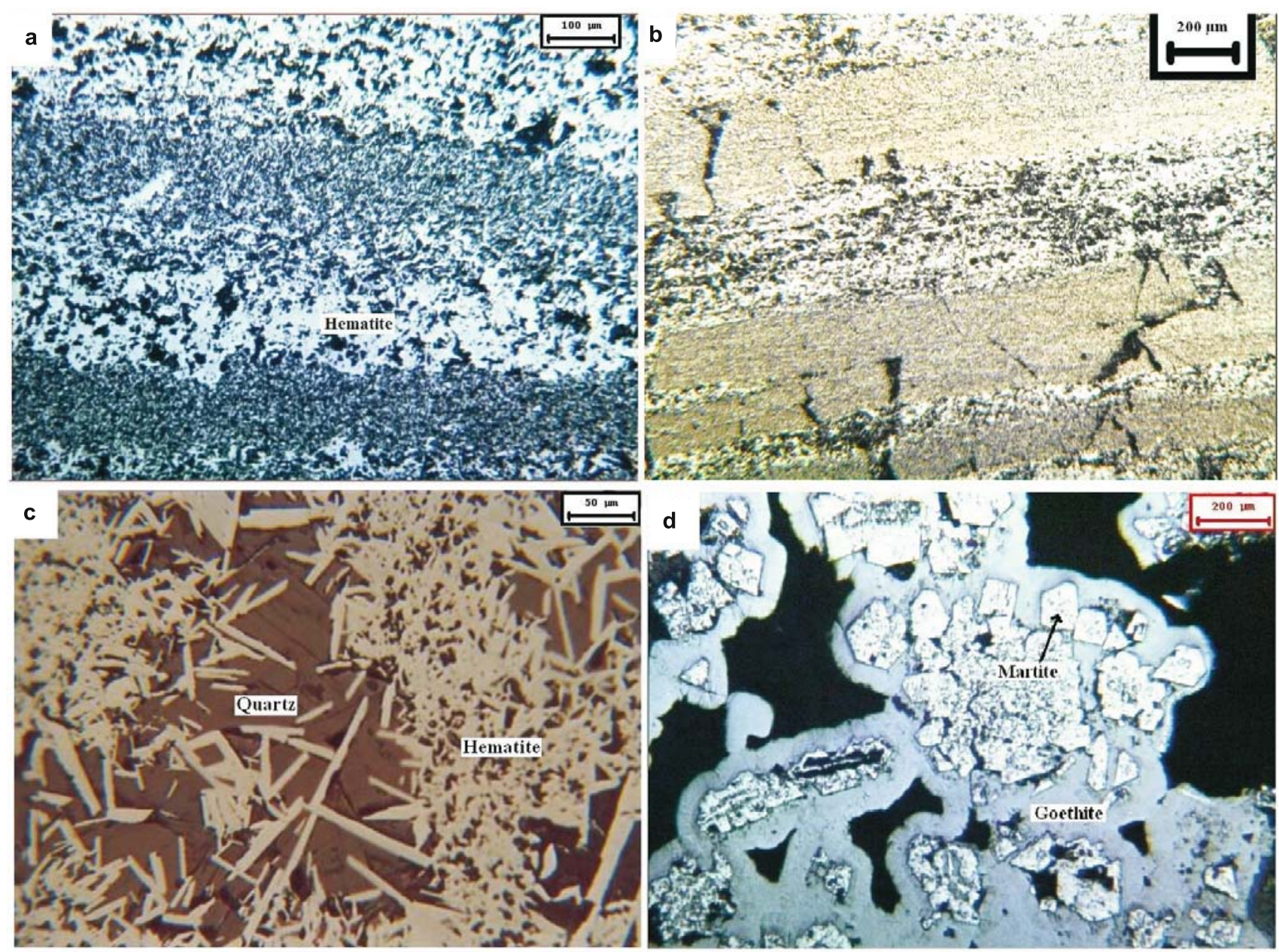

Figure 5. Photomicrographs of iron ore samples under reflected light microscope, (a) bands of specular hematite in hard laminated ore, (b) the alternate bands of hard laminated ore shows contrasting mineralogical association and texture, (c) presence of very minor silica in the interstitial spaces in hard laminated ore, and (d) goethite occurs as voids and cavities in martite-goethite ore.

India using Inductively Coupled Plasma Mass Spectrometer (ICP-MS), model Perkin Elmer Sciex ELAN DRC II. To ensure precision of data, international ore standards FeR-1 was analyzed along with the samples. The sample preparation, analytical procedure, precision and accuracy used for analyzing trace and REE are per Zahida Begum et al (2007).

\section{Mineralogical characterization}

Iron ore minerals associated with Precambrian banded iron formations are mainly found in three oxy-hydroxy phases as hematite, martite and goethite. The ore minerals and their textural features in BHJ, different types of iron ores along with shales are described in the following sections.

\subsection{Banded hematite jasper}

In banded hematite jasper, hematite is characterized by alternating bands/laminations with jasper.
Bands are generally parallel (figure 4a) and continuous but 'pinching and swelling' feature is also recorded. Some of the samples are martitized revealing a relict magnetite phase in these rocks (figure $4 \mathrm{~b}$ ).

\subsection{Massive ore}

Hematite grains are fine grained and tightly packed forming as a compact mass in this type of ore. Martite is very common in this type of ore (figure 4c). Fine-to-medium grained martite and microplaty crystals of hematite (specularite) are intricately associated with each other leaving very fine intergranular micro pore spaces (figure $4 \mathrm{~d}$ ).

\subsection{Hard laminated ore}

Hard laminated ores are steel grey in color and are relatively high grade. They consist of massive hematite with bands of specular hematite 

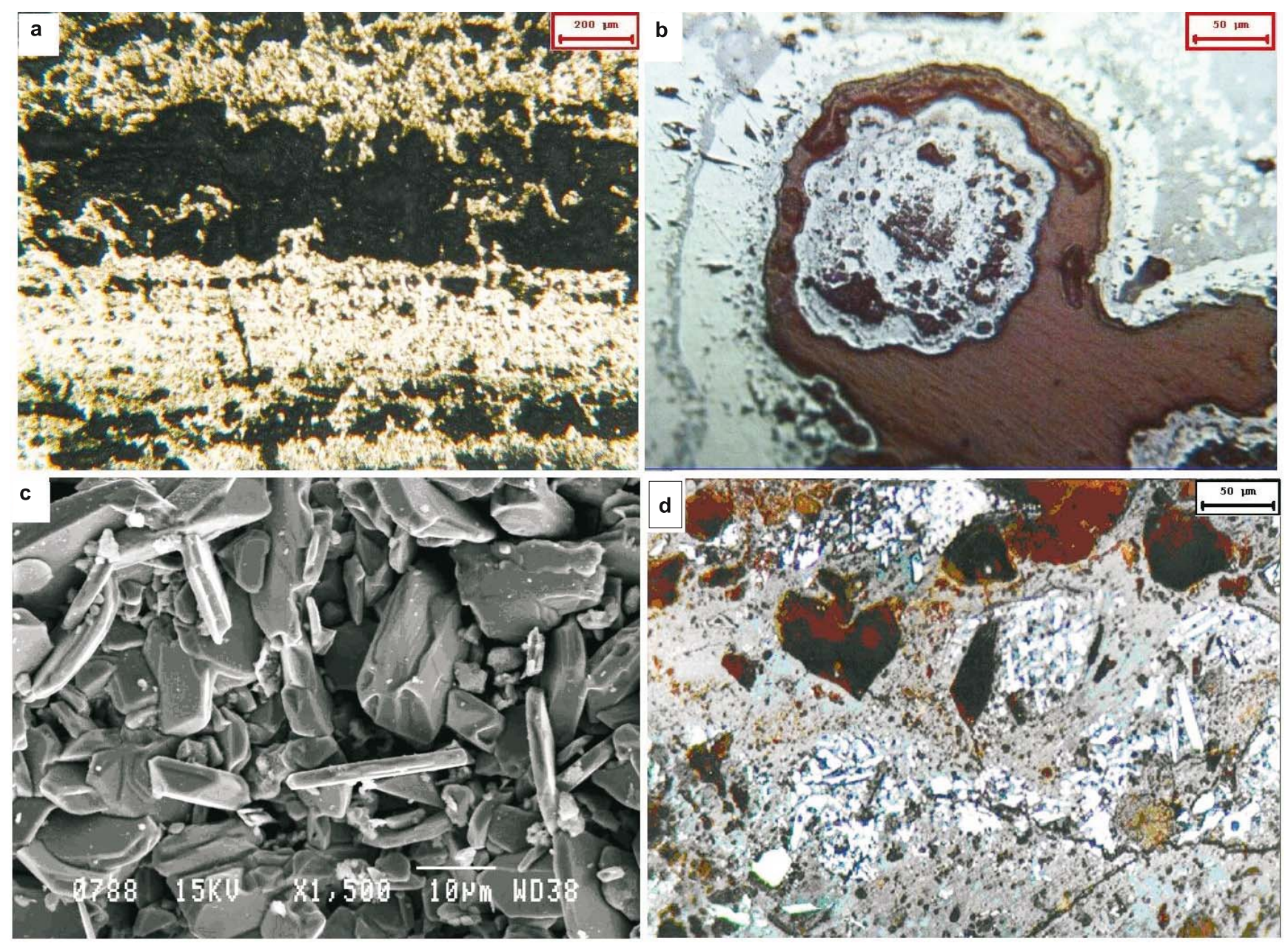

Figure 6. Photomicrographs of iron ore samples under reflected light microscope, (a) highly porous and fragile lamellae in soft laminated ore, (b) goethite occurs as colloform bands and as vein filling within the voids and cavities in goethitic-lateritic ore, (c) SEM photograph of blue dust shows fine powdery material mainly composed of micro-platy hematite and martite, and (d) hematite and goethite in flaky friable ore.

(figure 5a) which exhibit similar pattern as of BHJ (figure 4a). Presence of microfractures in alternating bands confirms their origin from BHJ (figure 5b). During the formation of hard laminated ore, the secondary hematite emplacement occurs in the place of Jasper band of BHJ. Further the presence of very minor silica in the interstitial spaces (figure 5c) strongly indicates their formation from BHJ.

\subsection{Martite-goethite ore}

In this type of ore, martite is the prominent iron bearing minerals along with goethite which occur as voids and cavities (figure 5d). Precipitation of goethite in the voids has resulted due to the leaching out of pre-existing minerals.

\subsection{Soft laminated ore}

In this type of ore, individual lamellae measure from a few millimeters to centimeters in thickness and the ore is highly porous and fragile (figure 6a). The principle ore and gangue minerals are same as that of hard laminated ore. They are relatively rich in goethite, kaolinite and gibbsite. The texture of soft laminated ore is almost similar to hard laminated ore but there are many voids between the lamellae, which are at times filled with secondary goethite and clay.

\subsection{Goethitic-lateritic ore}

Goethitic-lateritic ore is highly spongy and porous in nature. Goethite occurs as colloform bands and vein filling within the voids and cavities (figure 6b) which is resulted due to the leaching out of preexisting minerals.

\subsection{Blue dust}

Blue dust is steel grey in colour and occurs as minor pockets and the patches which are randomly oriented along major fractures or joints or 
near the top of the ore horizon as thin but persistent beds. The blue dust is mostly a fine powdery material mainly composed of microplay hematite and martite (figure 6c). Presence of martite in blue dust indicates their origin by desilisification process from banded iron ore.

\subsection{Flaky-friable ores}

Flaky-friable ore consists of hematite and martite as primary minerals and goethite, limonite, and gibbsite as secondary minerals (figure 6d). They are similar to the soft laminated ore, but having higher alumino-silicate minerals (kaolinite and gibbsite) compared to soft laminated ore.

\subsection{Shale}

Microscopic examination of lower shale samples reveals the pyroclastic texture of the rock that mainly contains kaolinite and quartz. SEM-EDS data indicates that the shale is enriched in $\mathrm{Si}$ compared to upper and middle shales (figure 7a). Middle shale comprises of hematite, goethite and kaolinite in variable proportions. SEM-EDS data of this shale shows the enrichment of iron compared to upper and lower shales. Small nodular precipitation of iron minerals can be seen from SEMEDS (figure 7b) making it enriched in iron. Upper shale in general comprises of gibbsite as major phase along with kaolinite and goethite. SEM-EDS observation shows that the upper shale is enriched in $\mathrm{Al}$ compared to the middle and lower shales (figure 7c).

\section{Geochemistry of the ores}

The major, trace and REE data provide information about genetic evolution of different types of ores and their possible precursor components. The major element contents of different types of iron ores and shales from Jilling-Langalata are given in tables 1-4. Trace and rare earth elements have been analyzed from five representative iron ore and upper shale samples from Jilling-Langalata deposits (tables 5 and 6).

\subsection{Major elements}

Major element analysis reveals that the BHJ contains very little amounts of $\mathrm{Al}_{2} \mathrm{O}_{3}, \mathrm{TiO}_{2}, \mathrm{CO}_{2}$, $\mathrm{MgO}, \mathrm{MnO}_{2}$ and $\mathrm{CaO}$. In typical BHJ with least alteration, the $\mathrm{Fe}$ is around $40 \%$ and the total $\mathrm{Fe}_{2} \mathrm{O}_{3}$ in the BHJ of Jilling-Langalata ranges from 40.75 to $65.04 \%$. The marked enrichment of iron in all ore samples are attributed to the effective removal of $\mathrm{SiO}_{2}, \mathrm{MgO}$ and $\mathrm{CaO}$ (Gutzmer et al
2008). In the BHJ, alumina content varies between 0.7 and $2.8 \%$ with an average of $1.88 \%$. In low grade iron ore, kaolinite and gibbsite are the chief alumina bearing minerals. Average alumina content in associated shales is very high (table 4). In iron ores and shale, alumina shows an inverse relation with iron (figure 8). In iron ore samples, associated shales are believed to be the main source of alumina bearing minerals. Alumina is relatively less mobile than iron and much less than silica and therefore undergoes residual enrichment. In lateritic iron ore, the higher values of alumina are believed to be due to the residual enrichment process, formed from early ferruginious shale. Since geochemical mobility of iron, alumina, silica and manganese compounds are different and hence tend to be separately precipitated during the secondary enrichment (Ramanaidou et al 2008).

The $\mathrm{TiO}_{2}$ concentration ranges between $0.035 \%$ and $0.062 \%$ in the BHJ and from $0.04 \%$ to $0.74 \%$ on an average in the iron ores. The BHJ of JillingLangalata deposits are pure chemical precipitates and hence have low $\mathrm{Al}_{2} \mathrm{O}_{3}$ and $\mathrm{TiO}_{2}$. Both $\mathrm{Al}_{2} \mathrm{O}_{3}$ and $\mathrm{TiO}_{2}$ simultaneously increase in laterite and shale (figure 8) represent a time of increased detrital input. BHJ and high grade ore are depleted in $\mathrm{CaO}+\mathrm{MgO}$, suggesting a near absence of calcite and dolomite which is also clear from the mineralogical information. $\mathrm{TiO}_{2}$ bears a positive correlation with $\mathrm{Al}_{2} \mathrm{O}_{3}$ in ores (figure 8). Aluminum and titanium are considered to be generally immobile during hydrothermal, diagenetic and weathering processes (MacLean and Kranidiotis 1987). Alkali content $\left(\mathrm{K}_{2} \mathrm{O}+\mathrm{Na}_{2} \mathrm{O}\right)$ of shales, lateritic ore and $\mathrm{BIF}$ shows considerable variation. Shale samples contain high $\mathrm{Na}_{2} \mathrm{O}$, but low $\mathrm{K}_{2} \mathrm{O}$ content (table 4), indicating that the source of the clastic component (including pyroclastic) was of variable composition.

A comparative study of the major element composition of Jilling-Langalata BHJ with BIF from other parts of the world shows that the values of $\mathrm{Al}_{2} \mathrm{O}_{3}, \mathrm{~K}_{2} \mathrm{O}, \mathrm{Na}_{2} \mathrm{O}, \mathrm{CaO}, \mathrm{MgO}$ and $\mathrm{P}_{2} \mathrm{O}_{5}$ are depleted in Jilling BHJ (figure 9). Average values of $\mathrm{Na}_{2} \mathrm{O}, \mathrm{K}_{2} \mathrm{O}, \mathrm{TiO}_{2}$ and $\mathrm{P}_{2} \mathrm{O}_{5}$ of the Jilling-Langalata shows close pattern with Hamersly and Kuruman iron formation. $\mathrm{MgO}$ and $\mathrm{CaO}$ are depleted in Jilling-Langalata iron ore deposit. Lepp and Goldisch (1964) estimated that the Precambrian iron formations contained smaller amounts of $\mathrm{Al}_{2} \mathrm{O}_{3}, \mathrm{TiO}_{2}, \mathrm{P}_{2} \mathrm{O}_{5}, \mathrm{CaO}$ and $\mathrm{MgO}$ than the post-Precambrian deposits. $\mathrm{Al}_{2} \mathrm{O}_{3}-\mathrm{SiO}_{2}-\mathrm{Fe}_{2} \mathrm{O}_{3}$ (figure 10) and $\mathrm{Fe}-$ $\mathrm{CaO}+\mathrm{MgO}-\mathrm{SiO}_{2}$ (figure 11) diagrams from the BHJ samples of the Jilling-Langalata iron formation suggest a closer chemical similarity to other Precambrian BIFs (Lepp and Goldich 1964; Govett 1966). 

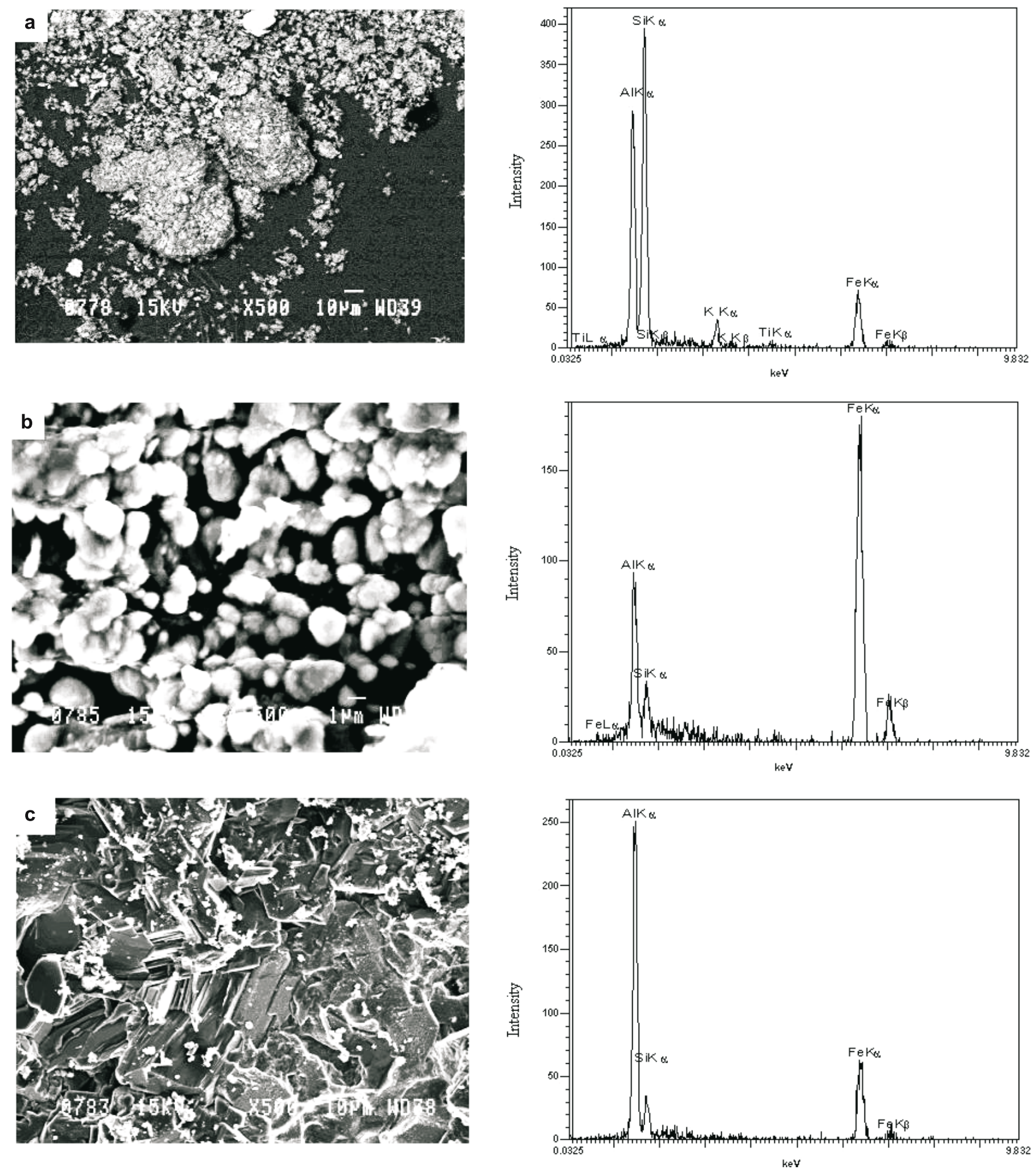

Figure 7. SEM photomicrographs of shale samples with EDS (a) lower shale, (b) middle or parting shale, and (c) upper shale.

The three shale members show contrasting major element contents (table 4). The lower shale member contains more silica and this high percentage of silica is due to the ubiquitous presence of quartz. In contrast to this, the middle shale member is enriched in $\mathrm{Fe}_{2} \mathrm{O}_{3}$ as it is inter-bedded with iron ores. The upper shale member shows almost similar $\mathrm{Al}_{2} \mathrm{O}_{3}$ content with middle shale member but lower $\mathrm{Fe}_{2} \mathrm{O}_{3}$. The shale samples are enriched in $\mathrm{Na}_{2} \mathrm{O}$ and $\mathrm{K}_{2} \mathrm{O}$ and the samples with high $\mathrm{K}_{2} \mathrm{O}$ reflect the micaceous nature of some of the terrigenous layers, whereas samples enriched in both 
Table 1. Major element constituents of banded hematite jasper in the Jilling-Langalata iron ore deposits of SinghbhumOrissa belt.

\begin{tabular}{|c|c|c|c|c|c|c|c|c|c|c|c|c|c|}
\hline Sample & $\mathrm{Fe}_{2} \mathrm{O}_{3}$ & $\mathrm{SiO}_{2}$ & $\mathrm{Al}_{2} \mathrm{O}_{3}$ & $\mathrm{CaO}$ & $\mathrm{MgO}$ & $\mathrm{P}_{2} \mathrm{O}_{5}$ & $\mathrm{Na}_{2} \mathrm{O}$ & $\mathrm{K}_{2} \mathrm{O}$ & Total S & $\mathrm{TiO}_{2}$ & $\mathrm{MnO}_{2}$ & LOI & Total \\
\hline BHJ1 & 49.3 & 47.04 & 1.5 & 0.09 & 0.06 & 0.0511 & 0.15 & 0.13 & 0.04 & 0.058 & 0.171 & 1.41 & 100.00 \\
\hline BHJ2 & 50.8 & 44.93 & 1.6 & 0.17 & 0.05 & 0.0432 & 0.15 & 0.06 & 0.04 & 0.058 & 0.163 & 1.93 & 99.99 \\
\hline BHJ3 & 45.75 & 50.49 & 1.5 & 0.16 & 0.09 & 0.0549 & 0.13 & 0.06 & 0.04 & 0.061 & 0.11 & 1.56 & 100.01 \\
\hline BHJ4 & 47.3 & 48.84 & 1.8 & 0.19 & 0.08 & 0.0545 & 0.15 & 0.09 & 0.04 & 0.061 & 0.132 & 1.26 & 100.00 \\
\hline BHJ5 & 51.1 & 45.12 & 1.5 & 0.13 & 0.32 & 0.0525 & 0.14 & 0.14 & 0.04 & 0.05 & 0.154 & 1.25 & 100.00 \\
\hline BHJ6 & 51.6 & 44.09 & 2 & 0.21 & 0.18 & 0.0592 & 0.17 & 0.11 & 0.04 & 0.035 & 0.085 & 1.42 & 100.00 \\
\hline BHJ7 & 51.2 & 45.35 & 1.2 & 0.09 & 0.12 & 0.045 & 0.13 & 0.13 & 0.04 & 0.046 & 0.055 & 1.59 & 100.00 \\
\hline BHJ8 & 60.87 & 36.25 & 1 & 0.17 & 0.14 & 0.0432 & 0.16 & 0.06 & 0.04 & 0.046 & 0.055 & 1.17 & 100.00 \\
\hline BHJ9 & 61.5 & 34.52 & 2 & 0.19 & 0.16 & 0.0592 & 0.15 & 0.07 & 0.04 & 0.046 & 0.065 & 1.2 & 100.00 \\
\hline BHJ10 & 64.8 & 31.61 & 1.2 & 0.24 & 0.15 & 0.0458 & 0.16 & 0.06 & 0.04 & 0.045 & 0.075 & 1.57 & 100.00 \\
\hline BHJ11 & 65.04 & 29.86 & 2.4 & 0.26 & 0.21 & 0.0412 & 0.15 & 0.08 & 0.04 & 0.045 & 0.055 & 1.82 & 100.00 \\
\hline BHJ12 & 60.13 & 34.85 & 2.3 & 0.25 & 0.09 & 0.0425 & 0.16 & 0.09 & 0.04 & 0.061 & 0.154 & 1.83 & 100.00 \\
\hline BHJ13 & 59.5 & 35.54 & 2.7 & 0.08 & 0.19 & 0.0323 & 0.15 & 0.05 & 0.04 & 0.061 & 0.198 & 1.46 & 100.00 \\
\hline BHJ14 & 37.26 & 57.78 & 2.5 & 0.18 & 0.22 & 0.0412 & 0.16 & 0.05 & 0.04 & 0.061 & 0.056 & 1.65 & 100.00 \\
\hline BHJ15 & 36.6 & 58.2 & 2.5 & 0.2 & 0.19 & 0.0518 & 0.15 & 0.08 & 0.04 & 0.056 & 0.085 & 1.85 & 100.00 \\
\hline BHJ16 & 61.44 & 33.11 & 2.8 & 0.21 & 0.21 & 0.0413 & 0.14 & 0.09 & 0.04 & 0.061 & 0.055 & 1.8 & 100.00 \\
\hline BHJ17 & 41.4 & 55.37 & 0.7 & 0.19 & 0.23 & 0.0425 & 0.17 & 0.12 & 0.04 & 0.056 & 0.095 & 1.59 & 100.00 \\
\hline BHJ18 & 40.75 & 54.31 & 2.3 & 0.16 & 0.06 & 0.0512 & 0.15 & 0.15 & 0.04 & 0.062 & 0.081 & 1.89 & 100.00 \\
\hline BНJ19 & 41.15 & 53.93 & 2.3 & 0.09 & 0.13 & 0.0549 & 0.17 & 0.13 & 0.04 & 0.062 & 0.028 & 1.92 & 100.00 \\
\hline
\end{tabular}

Table 2. Major element constituents of hard laminated ore (HLO), soft laminated ore (SLO) and lateritic ore (LO) in the Jilling-Langalata iron ore deposits of Singhbhum-Orissa belt.

\begin{tabular}{|c|c|c|c|c|c|c|c|c|c|c|c|c|c|}
\hline Sample & $\mathrm{Fe}_{2} \mathrm{O}_{3}$ & $\mathrm{SiO}_{2}$ & $\mathrm{Al}_{2} \mathrm{O}_{3}$ & $\mathrm{CaO}$ & $\mathrm{MgO}$ & $\mathrm{P}_{2} \mathrm{O}_{5}$ & $\mathrm{Na}_{2} \mathrm{O}$ & $\mathrm{K}_{2} \mathrm{O}$ & Total S & $\mathrm{TiO}_{2}$ & $\mathrm{MnO}_{2}$ & LOI & Total \\
\hline HLO1 & 95 & 1.53 & 1.33 & 0.05 & 0.06 & 0.046 & 0.0412 & 0.078 & 0.042 & 0.041 & 0.187 & 1.56 & 99.97 \\
\hline HLO2 & 93.8 & 2.11 & 2.03 & 0.08 & 0.08 & 0.046 & 0.052 & 0.087 & 0.044 & 0.051 & 0.055 & 1.5 & 99.94 \\
\hline HLO3 & 95.1 & 1.62 & 1.4 & 0.05 & 0.09 & 0.022 & 0.042 & 0.065 & 0.043 & 0.042 & 0.055 & 1.47 & 100.00 \\
\hline HLO4 & 95.06 & 1.56 & 1.06 & 0.05 & 0.02 & 0.037 & 0.0406 & 0.062 & 0.065 & 0.044 & 0.055 & 1.95 & 100.00 \\
\hline HLO5 & 96.38 & 0.67 & 0.3 & 0.02 & 0.2 & 0.046 & 0.0356 & 0.044 & 0.042 & 0.042 & 0.055 & 2.17 & 100.00 \\
\hline HLO6 & 96.32 & 1.31 & 0.7 & 0.07 & 0.7 & 0.046 & 0.032 & 0.043 & 0.045 & 0.041 & 0.055 & 0.64 & 100.00 \\
\hline HLO7 & 95 & 1.65 & 1.5 & 0.09 & 0.2 & 0.023 & 0.0462 & 0.052 & 0.043 & 0.046 & 0.055 & 1.27 & 99.98 \\
\hline SLO1 & 89.5 & 5.8 & 1.8 & 0.11 & 0.06 & 0.046 & 0.042 & 0.051 & 0.043 & 0.047 & 0.055 & 2.45 & 100.00 \\
\hline SLO2 & 87.4 & 2.5 & 5.2 & 0.12 & 0.2 & 0.065 & 0.041 & 0.057 & 0.045 & 0.051 & 0.198 & 4.13 & 100.01 \\
\hline SLO3 & 83.64 & 7.1 & 4.7 & 0.15 & 0.09 & 0.055 & 0.05 & 0.076 & 0.043 & 0.072 & 0.055 & 3.97 & 100.00 \\
\hline SLO4 & 87.7 & 4.9 & 3.6 & 0.12 & 0.2 & 0.046 & 0.043 & 0.056 & 0.041 & 0.061 & 0.055 & 3.18 & 100.00 \\
\hline SLO5 & 85.9 & 5.3 & 4.2 & 0.06 & 0.07 & 0.046 & 0.054 & 0.068 & 0.043 & 0.051 & 0.055 & 4.1 & 99.95 \\
\hline LO1 & 55.5 & 18.02 & 14.89 & 0.13 & 0.07 & 0.096 & 0.12 & 0.129 & 0.074 & 0.86 & 0.211 & 9.8 & 99.90 \\
\hline LO2 & 64.15 & 14.85 & 12.82 & 0.14 & 0.11 & 0.062 & 0.11 & 0.06 & 0.084 & 0.705 & 0.055 & 6.8 & 99.95 \\
\hline LO3 & 79.11 & 6.42 & 5.32 & 0.05 & 0.2 & 0.062 & 0.13 & 0.12 & 0.044 & 0.625 & 0.11 & 7.8 & 99.99 \\
\hline LO4 & 57.05 & 16.87 & 14.76 & 0.14 & 0.13 & 0.09 & 0.143 & 0.15 & 0.053 & 0.84 & 0.211 & 9.5 & 99.94 \\
\hline LO5 & 70.81 & 11.52 & 9.52 & 0.06 & 0.07 & 0.066 & 0.143 & 0.072 & 0.061 & 0.612 & 0.084 & 6.97 & 99.99 \\
\hline LO6 & 67.34 & 13.31 & 10.85 & 0.07 & 0.08 & 0.076 & 0.133 & 0.13 & 0.054 & 0.66 & 0.214 & 7.08 & 100.00 \\
\hline LO7 & 53.5 & 19.11 & 16.57 & 0.08 & 0.12 & 0.969 & 0.098 & 0.15 & 0.065 & 0.852 & 0.211 & 8.2 & 99.93 \\
\hline
\end{tabular}

$\mathrm{N}_{2} \mathrm{O}$ and $\mathrm{K}_{2} \mathrm{O}$ most probably incorporated the felsic volcanoclastic debris (Rao and Naqvi 1995). The lower shale in Jilling area contain $0.84 \%$ of $\mathrm{Na}_{2} \mathrm{O}$ and $0.97 \%$ of $\mathrm{K}_{2} \mathrm{O}$ suggesting their origin from felsic volcanoclastic debris. The average oxide percentage values of various shale members fall in three different fields (figure 12) closely associated with tuffaceous volcanic/pyroclastics indicating a close genetic relation between the lower shale and volcanic tuff/pyroclastic rocks. 
Table 3. Major element constituents of martite-goethite ore (MGO) and blue dust in the Jilling-Langalata iron ore deposits of Singhbhum-Orissa belt.

\begin{tabular}{|c|c|c|c|c|c|c|c|c|c|c|c|c|c|}
\hline Sample & $\mathrm{Fe}_{2} \mathrm{O}_{3}$ & $\mathrm{SiO}_{2}$ & $\mathrm{Al}_{2} \mathrm{O}_{3}$ & $\mathrm{CaO}$ & $\mathrm{MgO}$ & $\mathrm{P}_{2} \mathrm{O}_{5}$ & $\mathrm{Na}_{2} \mathrm{O}$ & $\mathrm{K}_{2} \mathrm{O}$ & Total S & $\mathrm{TiO}_{2}$ & $\mathrm{MnO}_{2}$ & LOI & Total \\
\hline MGO1 & 88.54 & 4.32 & 3.24 & 0.11 & 0.087 & 0.057 & 0.043 & 0.053 & 0.041 & 0.043 & 0.167 & 3.23 & 99.93 \\
\hline MGO2 & 89.42 & 3.25 & 2.65 & 0.13 & 0.082 & 0.046 & 0.045 & 0.051 & 0.042 & 0.043 & 0.187 & 4 & 99.95 \\
\hline MGO3 & 87.72 & 4.36 & 3.5 & 0.11 & 0.093 & 0.056 & 0.053 & 0.056 & 0.043 & 0.045 & 0.198 & 3.7 & 99.93 \\
\hline MGO4 & 86.43 & 5.14 & 4.65 & 0.14 & 0.084 & 0.066 & 0.058 & 0.076 & 0.045 & 0.056 & 0.155 & 3.1 & 100.00 \\
\hline MGO5 & 86.38 & 5.34 & 4.65 & 0.098 & 0.098 & 0.065 & 0.059 & 0.067 & 0.044 & 0.053 & 0.128 & 3 & 99.98 \\
\hline BD1 & 94.55 & 1.89 & 1.23 & 0.02 & 0.2 & 0.046 & 0.054 & 0.065 & 0.038 & 0.051 & 0.045 & 1.8 & 99.99 \\
\hline BD2 & 95.76 & 1.77 & 0.67 & 0.02 & 0.2 & 0.046 & 0.043 & 0.064 & 0.037 & 0.04 & 0.045 & 1.3 & 100.00 \\
\hline BD3 & 95.86 & 1.75 & 0.55 & 0.02 & 0.2 & 0.046 & 0.042 & 0.076 & 0.041 & 0.045 & 0.045 & 1.3 & 99.98 \\
\hline $\mathrm{BD} 4$ & 95.13 & 2.42 & 0.91 & 0.02 & 0.2 & 0.046 & 0.042 & 0.064 & 0.042 & 0.057 & 0.045 & 1 & 99.98 \\
\hline BD5 & 91.36 & 4.18 & 2.14 & 0.02 & 0.2 & 0.046 & 0.061 & 0.068 & 0.044 & 0.058 & 0.045 & 1.7 & 99.92 \\
\hline BD6 & 90.74 & 4.32 & 2.11 & 0.02 & 0.2 & 0.046 & 0.063 & 0.073 & 0.037 & 0.051 & 0.045 & 2.2 & 99.91 \\
\hline
\end{tabular}

Table 4. Major element constituents of lower shale (LS), middle shale (MS) and upper shale (US) in the Jilling-Langalata iron ore deposits of Singhbhum-Orissa belt.

\begin{tabular}{llllllllllllll}
\hline Sample & $\mathrm{Fe}_{2} \mathrm{O}_{3}$ & $\mathrm{SiO}_{2}$ & $\mathrm{Al}_{2} \mathrm{O}_{3}$ & $\mathrm{CaO}$ & $\mathrm{MgO}$ & $\mathrm{P}_{2} \mathrm{O}_{5}$ & $\mathrm{Na}_{2} \mathrm{O}$ & $\mathrm{K}_{2} \mathrm{O}$ & Total S & $\mathrm{TiO}_{2}$ & $\mathrm{MnO}_{2}$ & $\mathrm{LOI}$ & $\mathrm{Total}$ \\
\hline US1 & 18.7 & 20.69 & 33.02 & 0.178 & 0.041 & 0.073 & 0.343 & 0.246 & 0.043 & 3.68 & 5.015 & 10.21 & 92.24 \\
US2 & 21.32 & 27.63 & 33.67 & 0.056 & 0.041 & 0.057 & 0.366 & 0.235 & 0.004 & 3.63 & 0.253 & 12.32 & 99.58 \\
US3 & 18.83 & 22.93 & 29.84 & 0.19 & 0.031 & 0.08 & 0.355 & 0.204 & 0.085 & 5.58 & 4.047 & 11.55 & 93.72 \\
US4 & 19.05 & 23.24 & 35.66 & 0.163 & 0.045 & 0.082 & 0.324 & 0.304 & 0.05 & 5.43 & 1.215 & 12.53 & 98.09 \\
US5 & 15.95 & 28.93 & 38.12 & 0.167 & 0.036 & 0.117 & 0.321 & 0.284 & 0.04 & 3.31 & 0.935 & 10.3 & 98.51 \\
& & & & & & & & & & & & & \\
MS1 & 50.25 & 16.7 & 23.18 & 0.013 & 0.052 & 0.055 & 0.529 & 0.02 & 0.04 & 0.59 & 0.056 & 8.4 & 99.89 \\
MS2 & 51.91 & 15.5 & 22.11 & 0.021 & 0.051 & 0.117 & 0.524 & 0.17 & 0.04 & 0.55 & 0.021 & 8.9 & 99.91 \\
MS3 & 54.12 & 12.46 & 21.89 & 0.012 & 0.065 & 0.057 & 0.437 & 0.13 & 0.04 & 0.72 & 0.057 & 9.9 & 99.89 \\
MS4 & 46.23 & 16.6 & 25.13 & 0.032 & 0.052 & 0.055 & 0.432 & 0.13 & 0.04 & 0.89 & 0.071 & 10.2 & 99.86 \\
MS5 & 45.6 & 18.4 & 23.97 & 0.16 & 0.058 & 0.05 & 0.535 & 0.129 & 0.04 & 0.96 & 0.068 & 9.9 & 99.87 \\
& & & & & & & & & & & & \\
LS1 & 27.82 & 39.67 & 19.16 & 0.137 & 0.087 & 0.048 & 0.81 & 1.84 & 0.04 & 0.94 & 0.043 & 9.32 & 99.92 \\
LS2 & 26.54 & 41.83 & 20.2 & 0.066 & 0.064 & 0.055 & 0.71 & 1.07 & 0.04 & 1.21 & 0.027 & 8.12 & 99.93 \\
LS3 & 25.46 & 45.14 & 19.52 & 0.144 & 0.083 & 0.053 & 0.871 & 0.129 & 0.04 & 1.05 & 0.049 & 7.36 & 99.90 \\
LS4 & 26.62 & 44.03 & 18.452 & 0.126 & 0.098 & 0.057 & 0.951 & 0.811 & 0.04 & 1.06 & 0.038 & 7.63 & 99.91 \\
LS5 & 24.7 & 43.93 & 18.6 & 0.186 & 0.075 & 0.055 & 0.932 & 1.11 & 0.04 & 1.68 & 0.014 & 8.63 & 99.95 \\
LS6 & 26.31 & 44.29 & 17.08 & 0.151 & 0.082 & 0.073 & 0.754 & 0.905 & 0.032 & 1.58 & 0.056 & 8.565 & 99.88 \\
\hline
\end{tabular}

\subsection{Trace and REE geochemsitry}

Trace and REE constituents play a significant role in deciphering the metallogenetic evolution and potentiality of the ore body. The trace element data is presented in table 5. Average trace element composition of Jilling BHJ is compared with the average trace elemental values of BIF's of Algoma type, superior type, average volcanogenic iron formation of erstwhile USSR and average BIF of Maru iron formation (table 5). The trace elements in general are depleted in Jilling samples but the associated shales are sufficiently rich in trace elements. Relatively high values of $\mathrm{Cr}$ and $\mathrm{Zr}$ in Jilling shale samples indicate the possibility of clastic component of igneous origin. BHJ have lower concentration of $\mathrm{U}$ compared to $\mathrm{Th}$, due to their slow rate of accumulation and hence shows exposure to sea water. Uranium in these samples varies from 0.39 to $0.70 \mathrm{ppm}$ while thorium varies from 0.45-3.05 ppm.

In terms of individual values, $\mathrm{Ni}, \mathrm{Cu}$ and $\mathrm{Zn}$ of the Jilling BHJ have a near similarity to the Algoma type while the values of $\mathrm{Zr}$ and $\mathrm{Ba}$ are closer. However, the Jilling BHJ samples are depleted in $\mathrm{Co}, \mathrm{Sr}$ and $\mathrm{Y}$ values compared to the Algoma facies iron formation. Lower values of $\mathrm{Sr}$ and $\mathrm{Y}$ indicating the absence of source of crustal felsic rock, as these components are derived from weathering of crustal felsic rocks (Rao and Naqvi 1995). The supergene hematite-martite ores are characterized by distinctly elevated concentrations of $\mathrm{Sr}$ and $\mathrm{Ba}$ and efficient fractionation of LREE from HREE (Gutzmer et al 2008). 

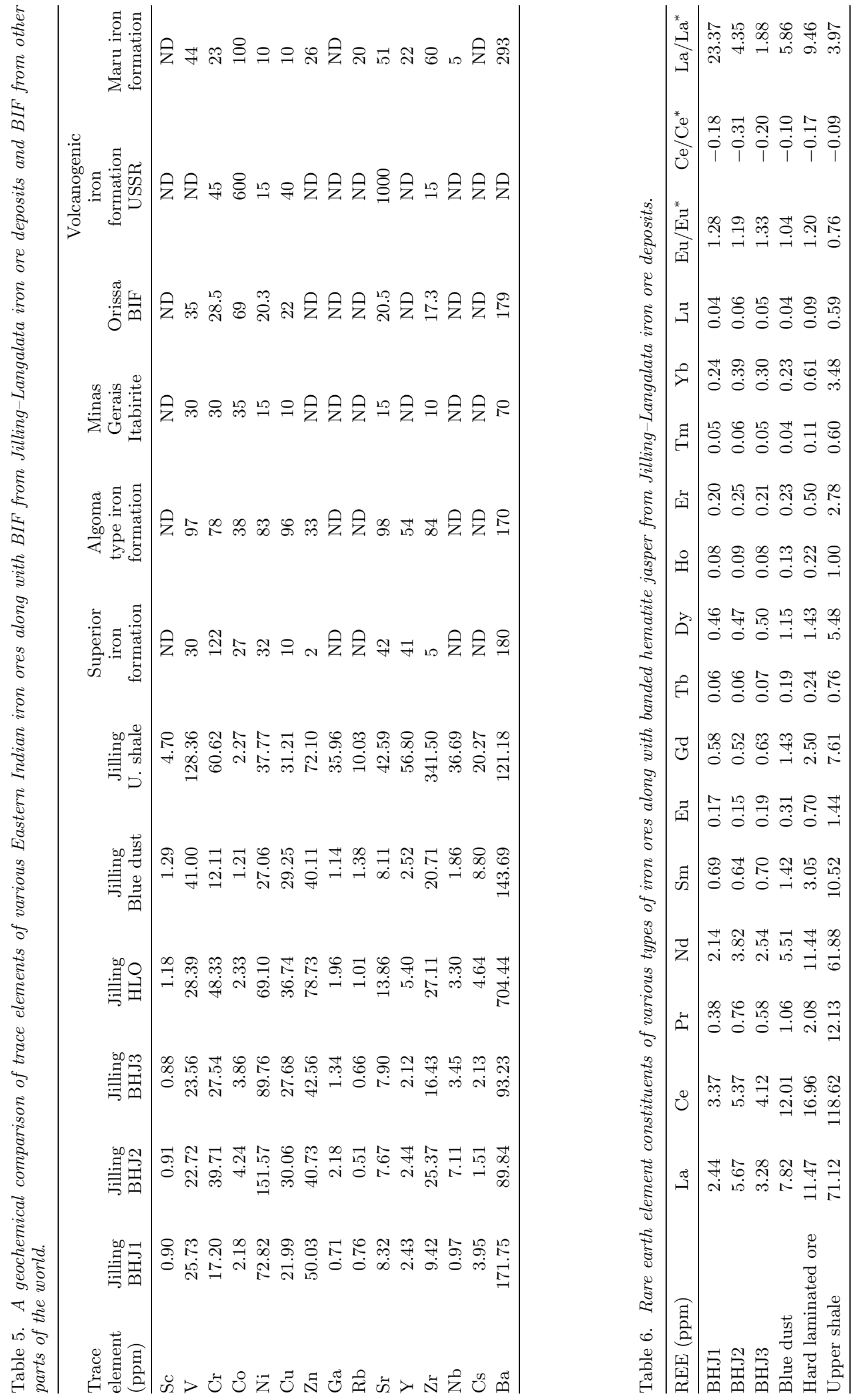
The REE data is presented in table 6. A synthesis of results reveals that the ore in general, are poor in rare earth elements. The summation of heavy rare earth element is found to be very low compared to LREE. Ore samples show decrease in concentration from LREE to HREE. In BHJ, the average HREE is only $2 \mathrm{ppm}$ in contrast to that of LREE (12 ppm). The REE normalized profile related to BHJ and iron ores are shown in figure 13. The REE values are normalized with PAAS (Post Archean Australian Shale) values. Most of the ore types have more or less similar normalized REE profiles though they differ widely in their absolute REE contents.

BHJ samples show positive $\mathrm{Eu}$ anomaly $\left(\mathrm{Eu} / \mathrm{Eu}^{*}=1.27\right.$ avg. $)$. REE patterns of iron ores including hard laminated ore and blue dust of Jilling deposits also show positive Eu anomaly as $\mathrm{Eu} / \mathrm{Eu}^{*}=1.20$ and 1.04 respectively, signifying that the solutions which brought $\mathrm{FeO}$ and $\mathrm{SiO}_{2}$ to the ambient ocean were derived from a reducing environment. The increase in LREE could have been accentuated during the formation of magnetite and microplaty hematite to form anhedral hematite which has favoured relative increase of HREE in residual fluid. The increase in the REE suggests the possible presence of $\mathrm{Fe}$ in the mineralizing fluid (Figueiredo E Silva et al 2008). The Jilling BHJ samples also have positive La anomaly and slightly negative Ce anomaly.

\section{Discussion}

\subsection{Genesis of banded iron ore}

BIF has been reported from different parts of the world and the source of $\mathrm{Fe}$ and $\mathrm{Si}$ within $\mathrm{BIF}$ is an intriguing problem (Holland 1973; Alibert and MacCulloch 1993; Beukes and Gutzmer 2008). Mid-oceanic ridge or hot spot style tectonic setting are likely settings from where iron could have released during these tectonic activities (Holland 1973; Morris and Horwitz 1983; Dalstra and Rosierie 2008). The several giant and worldclass ore systems were formed during intra-plate tectono-thermal and rifting events (Pirajno and Bagas 2008). Iron was scavenged from the early Archean oceanic crust and re-deposited on the ocean floor by hydrothermal fluids aiding the deposition of BIFs (Polat and Frei 2005). It is difficult to attribute a single depositional model for the formation of BIFs and the reason for lack of uniform genetic model may be attributed to their formation at long span of depositional episodes during Precambrian time, differences in geological condition and depositional environments from place to place.
The relationship between $\Sigma(\mathrm{Co}+\mathrm{Cu}+\mathrm{Ni})$ and RREE of hydrothermal and hydrogenous deposits are used by Dymek and Klein (1988); Klein and Beukes (1989) to reconstruct the fields of hydrothermal and hydrogenous deposits (figure 14). Most of the samples of JillingLangalata BIF's fall within the field of hydrothermal deposits (figure 14), which also suggest that a major part of the iron in the studied banded ironformations were added to the bottom sea water by hydrothermal solutions derived from hydrothermally active marine environments.

BHJ samples show positive $\mathrm{Eu}$ anomaly $\left(\mathrm{Eu} / \mathrm{Eu}^{*}=1.27\right.$ avg.). REE patterns (figure 13) of iron ores including hard laminated ore and blue dust of Jilling deposits also show positive $\mathrm{Eu}$ anomalies $\left(\mathrm{Eu} / \mathrm{Eu}^{*}=1.20\right.$ and 1.04 respectively). Ore samples show decrease in concentration from LREE to HREE. Possible source materials of positive Eu anomaly of BIFs have been attributed to hydrothermal solutions (Michard and Albarede 1986; Campbell et al 1988) and/or detrital feldspar. Because the $\mathrm{Al}_{2} \mathrm{O}_{3}$ content of BIFs in JillingLangalata deposits is very low, the positive $\mathrm{Eu}$ anomaly of BIFs was not caused by detrital mineral assemblages but possible through influence of hydrothermal solutions. The hydrothermal fluids are high in silica and low in alumina causing the precipitation of alumina-poor iron silicates that dissociate into iron hydroxide and amorphous silica during diagenesis. The silica is typically entrapped by iron oxide laminae to form bands of chert.

The BIF samples of Jilling are depleted in REE and other trace elements and are characteristically similar to those of hydrothermal fluids and metalliferous deposits of near mid-oceanic ridges (Kato et al 1996, 1998; Khan et al 1996). Hydrothermal solutions emplaced in present-day oceans at the East Pacific Rise (EPR), MidAtlantic Ridge (MAR) and Red Sea (RS) are depleted in $\Sigma$ REE and have positive Eu anomalies (Derry and Jacobsen 1990). The genetic relation of Jilling-Langalata BIF/BHJ with volcanism can be indicated by the presence of pyroclastic material including lava, which lies below the lower shale. On the other hand, the lower shale (figure 12) seems to be the continuation of this lava formation. The sharp contact of these lower shale and BIF indicate the volcanic association of BIF.

La enrichment in banded hematite jasper is noteworthy $\left(\mathrm{La} / \mathrm{La}^{*}=5.18\right)$. La enrichment has been noticed in the sediments of the Red Sea and BIF's of some Archean greenstone belts (Barrett et al 1988; Manikyamba et al 1993). Negative Ce anomalies have been observed in BHJ, hard laminated ore, blue dust and shale. Ce depletion is a feature found in the BIF of the Transvaal supergroup, South Africa (Beukes and Klein 1990). 
Mineralogy and geochemistry of banded iron formation and iron ores
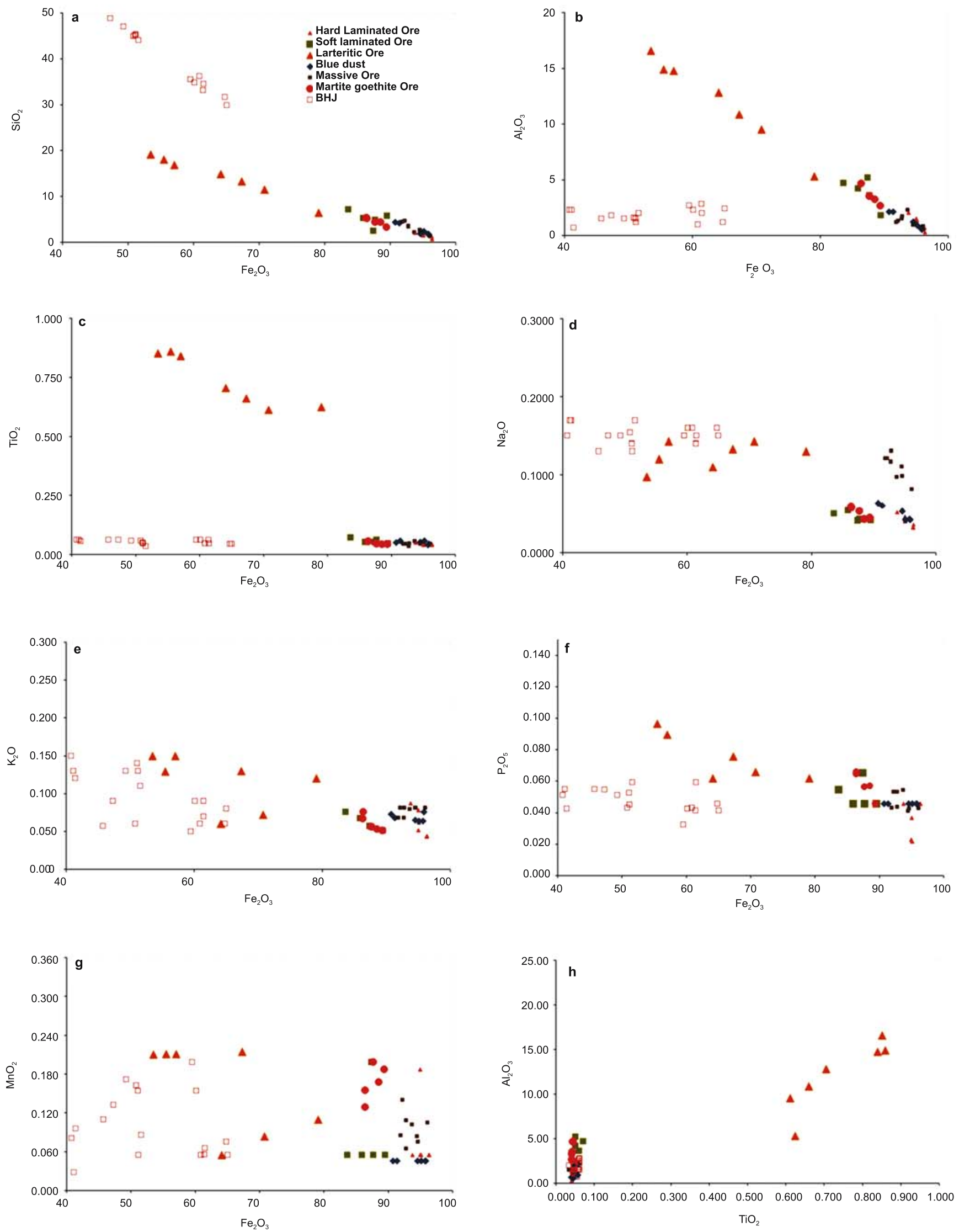

Figure 8. Binary relations of some selected trace elements in various types of iron ores and banded hematite jasper. 


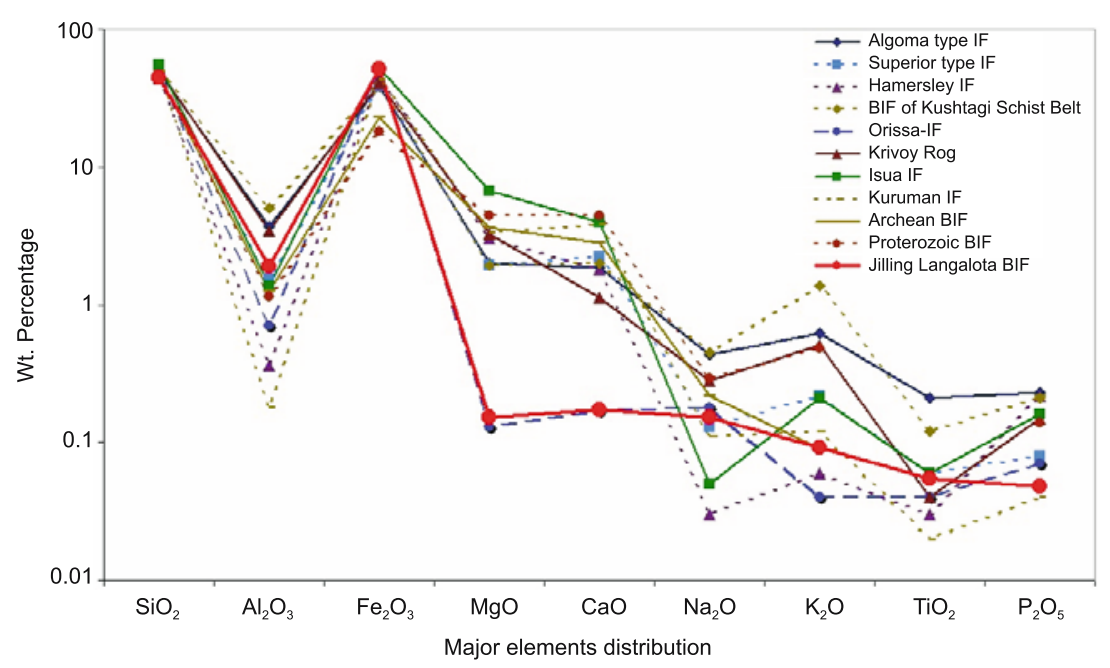

Figure 9. Variation in chemical composition of Jilling BIF and BIF from other parts.

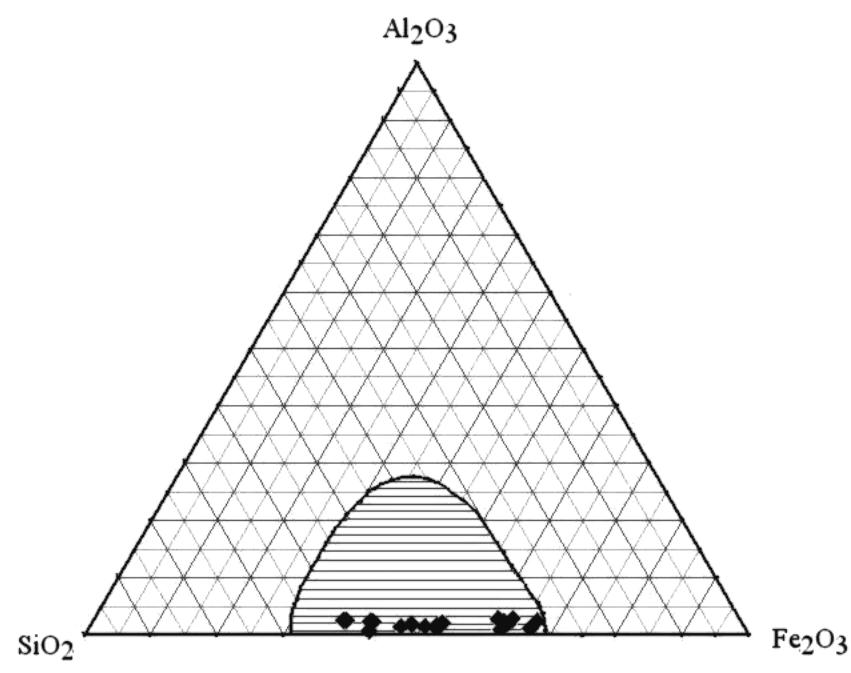

Figure 10. Composition of Jilling BIF plotted within the Precambrian field (after Govett 1966).

The present-day sea water is generally characteristic of a strong negative Ce anomaly because of Ce oxidation and removal (Elderfield and Greaves 1982; De Baar et al 1985). The slight negative or no Ce anomaly of BIFs suggests that sea water older than $3.4 \mathrm{Ga}$ had no Ce anomaly and was less oxic than modern sea water. Jilling BIF has also slightly negative $\mathrm{Ce}$ anomaly, hence the depleted nature of $\Sigma$ REE and positive $\mathrm{Eu}$ anomalies in Jilling BIF indicate that their metal content was added to ambient oceans by hydrothermal solutions at hydrothermally active off-shelf environment.

\subsection{Genesis of different ore types}

High-grade BIF-hosted deposits are the world's most important source of iron ore. Despite their economic significance, the origin of these deposits has long remained poorly constrained. Several

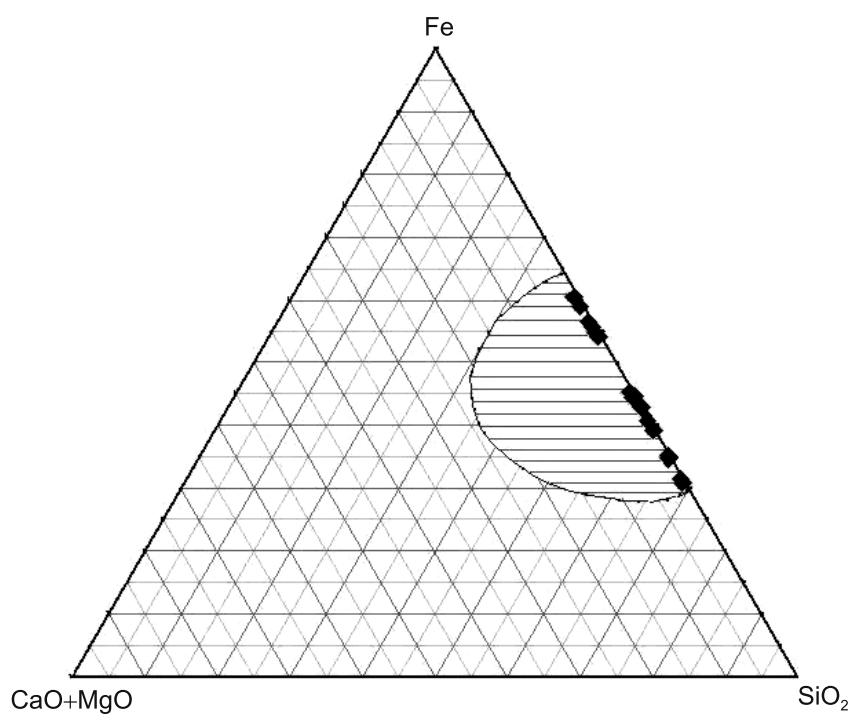

Figure 11. Composition of Jilling BIF plotted within the Precambrian field (after Lepp and Goldich 1964).

workers have postulated different metallogenetic models for these economically important deposits from time to time (Morris 1985; Harmsworth et al 1990; Beukes et al 2003; Dalstra and Guedes 2004; Clout 2006, etc.).

Supergene-modified hypogene-hydrothermal model involving warm basinal brines plus ascending or descending heated meteoric fluids for the upgradation of iron formation to form high-grade hematite ores have been suggested by some workers (Barley et al 1999; Hagemann et al 1999; Taylor et al 2001; Webb et al 2003; Dalstra and Guedes 2004; Thorne et al 2004; Lobato et al 2008). These models are based on the investigations in Hamersley District, Australia, in Quadrilatero Ferrifero, Brazil (Rosiere and Rios 2004), and in Sishen-Beeshoek District of South Africa (Gutzmer 


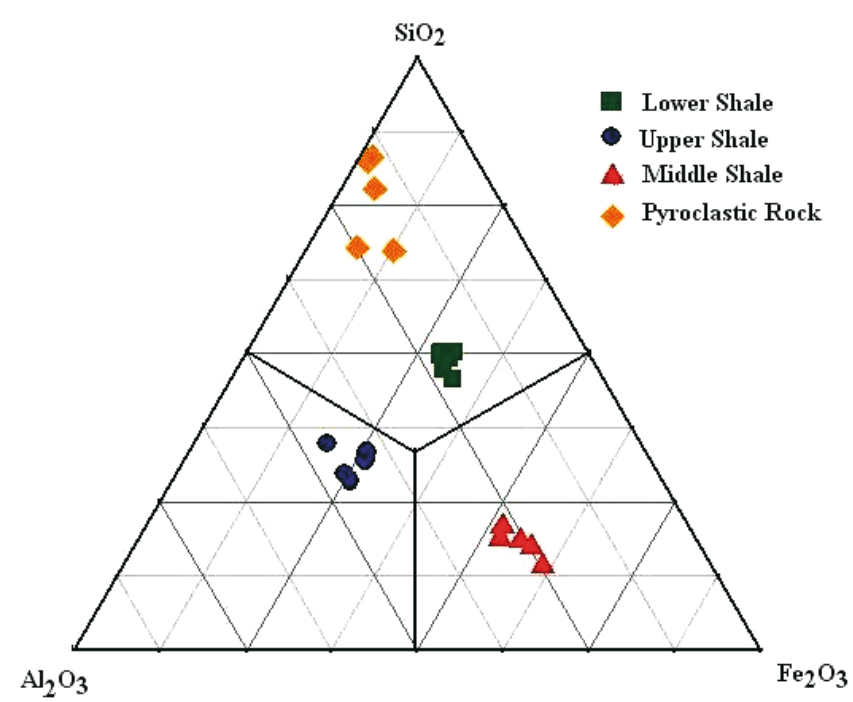

Figure 12. Triangular plots of $\mathrm{Al}_{2} \mathrm{O}_{3}, \mathrm{Fe}_{2} \mathrm{O}_{3}$ and $\mathrm{SiO}_{2}$ of samples from different shale formations.

and Beukes 1998). Webb and Clout (2008) reported that martite-goethite ore bodies are resulted from late Mesozoic supergene alteration of BIF across Hamersley Province. Hematite ore bodies formed at sites of repeated focused hydrothermal fluid flow with iron-ore formation was probably a longlived, multi-stage process spanning more than one billion years (Rasmussen et al 2007).

Silica removal is the principal control of enrichment from the protore (BIF). The loss of silica and redistribution of iron is the result of strong subtropical weathering (Cope et al 2008). Hypogene fluids have indeed played an important role in the evolution of these ores (Brown 2008). It has been found that high-grade iron ore is the result of sequential removal and replacement of gangue minerals by hydrothermal and supergene process and host BIF structure is the most important control for these deposits (Alchin et al 2008; Dalstra and Rosiere 2008). Thus hydrothermal alteration is structurally controlled and the proximal alteration zone represents the high-grade ore (Figueiredo E Silva et al 2008).

Hard ores rich in hematite and martite in most of the Indian deposits are believed to have formed during early hydrothermal events (Mukhopadhyay et al 2008). Chemical weathering in wet tropical humid-monsoonal climate resulted in extensive supergene modification of these hydrothermally upgraded iron ores to hematite-martite ore (Beukes et al 2008). Hard hematite-martite ores in Noamundi region was formed by hydrothermal replacement of BIF protolith through leaching of silica and introduction of iron by hydrothermal fluids of meteoric origin (Beukes et al 2008).

The iron ore of Jilling-Langalata can be broadly divided in to seven categories. They are massive, hard laminated, soft laminated, martite-goethite, powdery, blue dust and lateritic ore. All these types of iron ores occur in close association of BIF. There is a difference of opinion regarding the origin of iron ore in Singhbhum and Orissa Craton. Although it is more or less accepted that the parent rock of iron ore is BHJ, the presence of disseminated martite in BHJ suggests that the magnetite of protore was

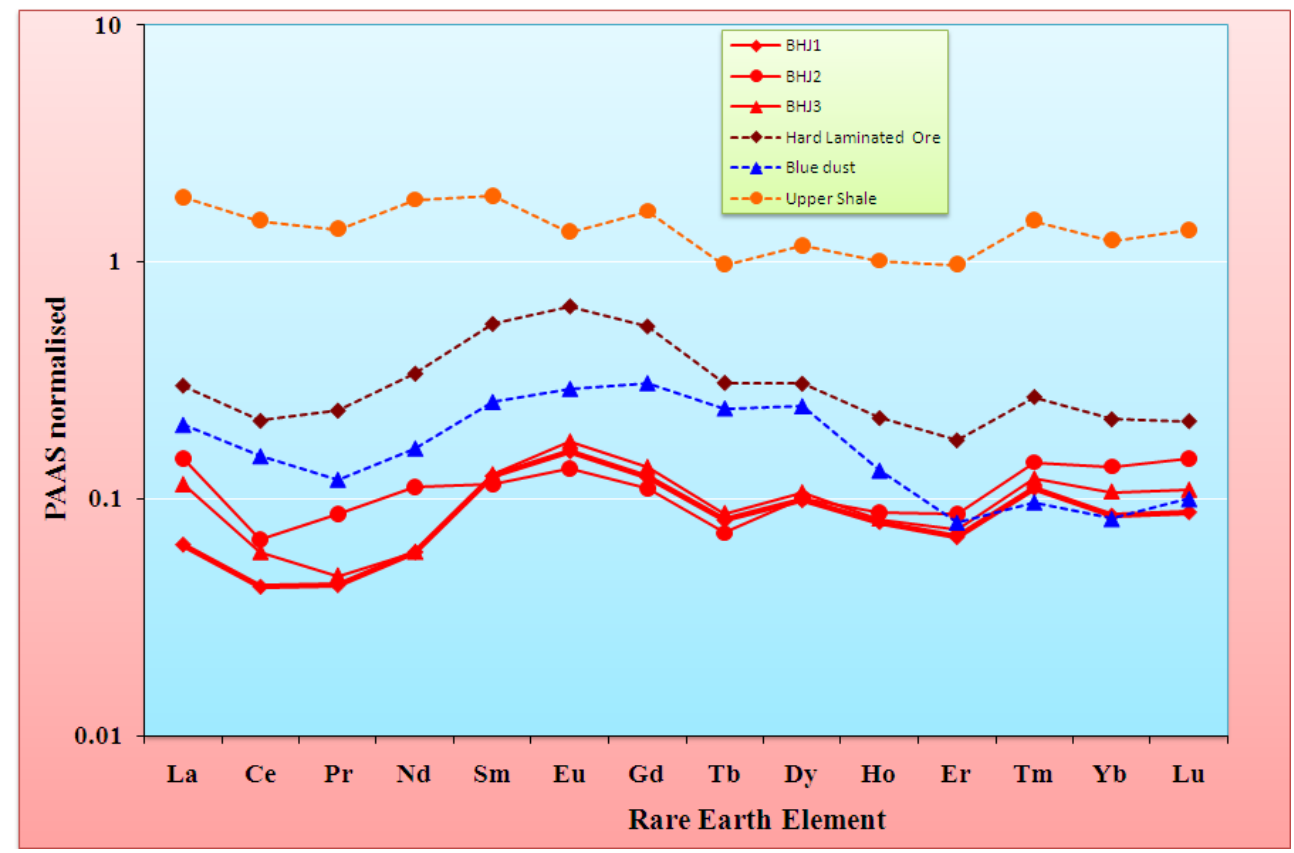

Figure 13. PAAS normalized rare earth abundances of the Jilling-Langalata banded iron formations and associated ores. 


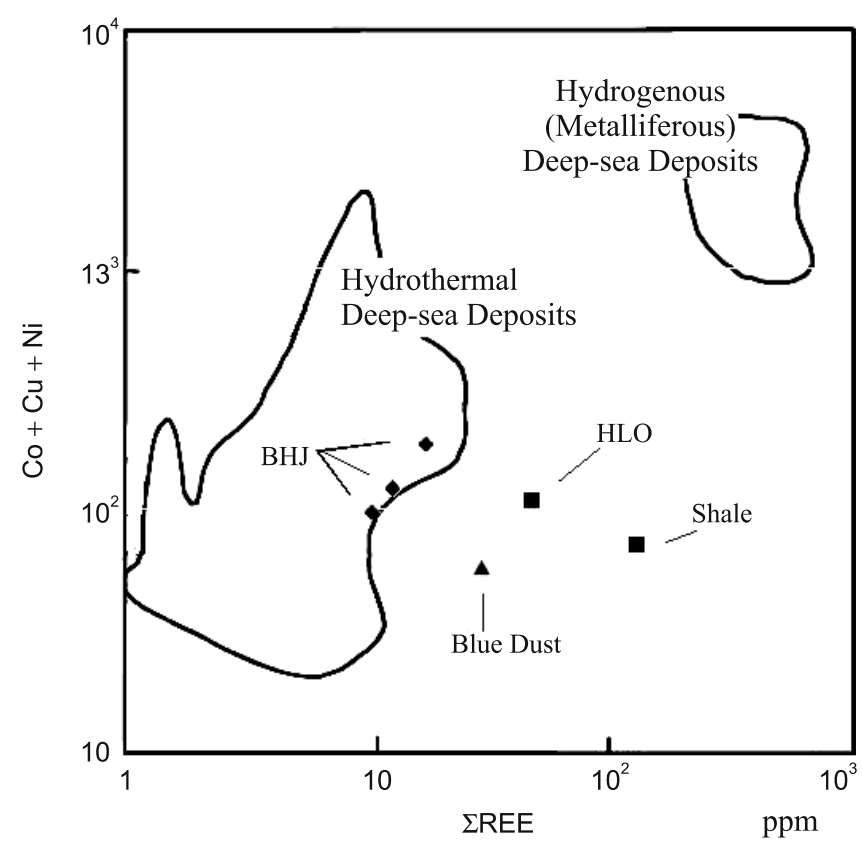

Figure 14. Relationship between $\Sigma \mathrm{REE}$ and $\mathrm{Co}+\mathrm{Cu}+\mathrm{Ni}$. Most of the BIF samples fall within or very close to the field of hydrothermal deposits.

converted to martite. The different types of iron ore are intimately associated with BHJ. The different textural relationships and field occurrences of iron ores show that combination of different processes rather than single one was responsible for the formation of different type of iron ores. A comparative study of trace element data of Jilling BHJ shows a similar pattern with that of hard laminated ore and blue dust (figure 15) indicating the formation of these iron ores from BHJ.
In the study area, possible genesis of high-grade hematite ore could have occurred in two steps. In the first stage, shallow, meteoric fluids affect primary, unaltered BIF by simultaneously oxidizing magnetite to martite and replacing quartz with hydrous iron oxides. In the second stage of supergene processes, deep burial upgrades the hydrous iron oxides to microplaty hematite (figure 16). The hard laminated ores are found in close association with BHJ. Small and large-scale faults and folds similar to those in BIF are also common in the hard laminated ore body. Replacement features, depletion of silica and distinct evidence of leaching out of silica bands from BHJ (figure 16) strongly suggest that these iron ores were formed from BHJ through desilicification process. Alkaline-rich solution was responsible for removal of silica. However, it is difficult to know the exact source of solution, which was responsible for the replacement of silica. The porosity of hematite lamina is presented as evidence of leaching of primary silica by alkaline fluids, which subsequently precipitated ferric hydroxide as a precursor to goethite and eventually hematite (van Schalkwyk and Beukes 1986).

Initial upgradation of BHJ to high-grade iron ore was related to hydrothermal solution processes caused by a variety of ascending and/or descending hydrothermal fluids that drive this enrichment process (Dalstra and Guedes 2004; McLellan et al 2004; Rosiere and Rios 2004; Webb et al 2004; Hagemann et al 2006; Rosiere et al 2006). Brown et al (2004) have shown the evidence of hydrothermal activity in the form of veins record in Mt. Whaleback deposits. During the desilicification processes, iron was also leached out

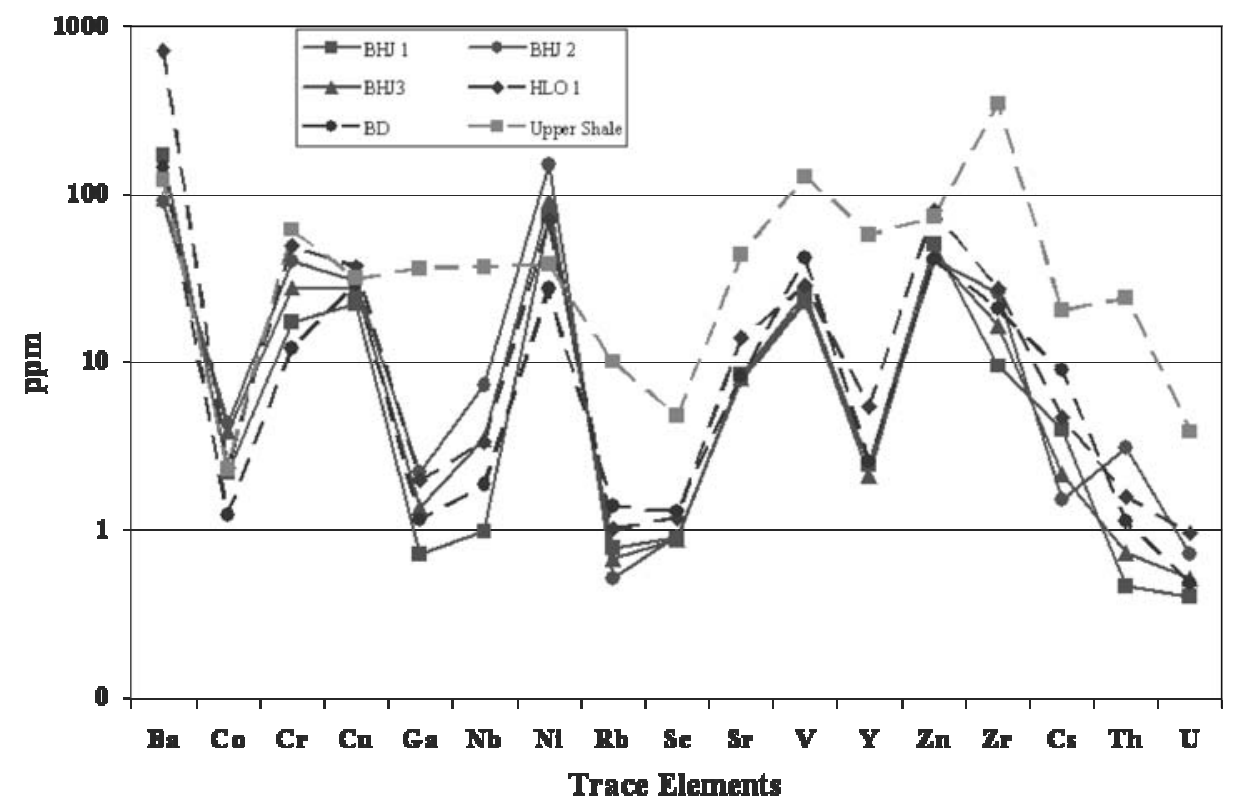

Figure 15. Trace element patterns of banded hematite jasper, different ore and upper shale from Jilling-Langalata deposits show a similar trend of trace elements of BHJ and different ore types. 

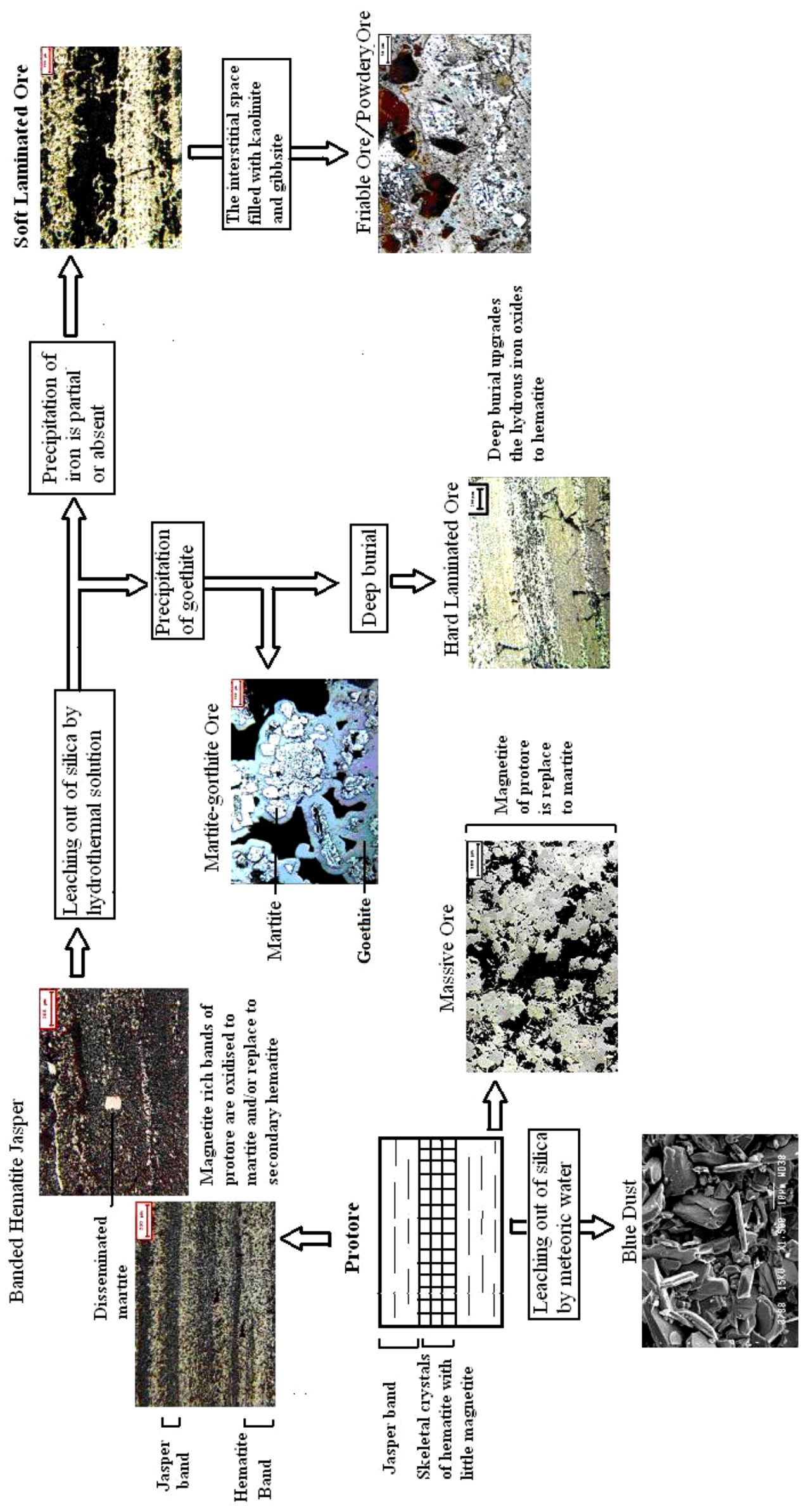

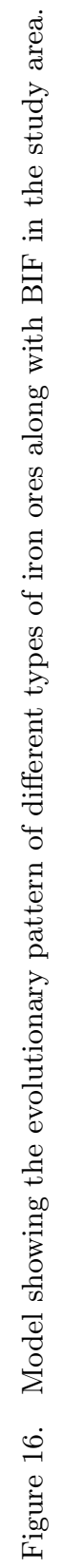


along with silica from BHJ (McLellan and Oliver 2008).

Removal of silica from BIF and successive precipitation of iron resulted in the formation of martite-goethite ore (figure 16). In martitegoethite ore secondary precipitated iron occur as hydrated form (goethite). The hard laminated ore has been formed in the second stage of supergene processes, where the deep burial upgrades the hydrous iron oxides to hematite. In this process, if the precipitation of iron in leached out space has been completed then martitegoethite ore and in the final stage deep burial upgrades it into hard laminated ore. Soft laminated ores were formed where precipitation of iron was partial or absent. In this case, the leached out space remains with time and the ore becomes very fragile in between the laminae. The interstitial space generally filled with kaolinite and gibbsite, which makes it low grade.

Massive iron ores on the other hand are devoid of any lamination. Field evidences and core drilling data suggest that the massive ore is usually associated with BHJ and lower shale. The thickness of the massive ore layer varies with the location. Small and large-scale faults and folds as observed in BHJ are also common in this type of ore. The massive iron ore grades in to well-developed bedded BHJ in depth. These observations suggest their syngenetic origin with BHJ. The massive ore type is mainly composed of martite and microplaty hematite and the martite may have been formed from the protore. Redox independent transformations may have been responsible for the formation of massive ore from BHJ (Otake et al 2007).

Blue dust occurs in association with BHJ as pockets and layers. Although blue dust and friable ore are both powdery ores, genetically they differ to a large extent. The BHJ in the region has been subjected to variable degrees of deformation, leading to the formation of folding, faulting and joints of complex nature produce favourable channels. Percolating waters play an important role in the formation of blue dust that percolates to deeper regions through these favourable planar features and the subterranean solution offers the necessary acidic environment for leaching of quartz from the BHJ. Beckwith and Reeve (1969) reported that the dissolution of quartz is extreme in the acidic environment. The quartz in the form silica gets dissolved in meteoric water and after its removal from the BHJ it precipitates away from the source in different forms. It occurs as vein-lets in adjoining areas associated with BHJ and other ore types. Hence from the chemical constraints, the dissolution of silica and other alkalis are responsible for the formation of blue dust. The friable and powdery ore on the other hand are formed by soft laminated ore (figure 16). As it is formed from the soft laminated ore, its alumina content remains high similar to soft laminated ore compared to blue dust.

\section{Conclusions}

Geochemistry of banded iron-formations of the Jilling-Langalata iron ore deposits belongs to Singhbhum-North Orissa Craton shows that they are detritus-free chemical precipitates. Strong Eu anomalies of the BIF along with ubiquitous presence of intercalated tuffaceous shales point towards genesis of the iron, which could have leached from sea floor by volcanogenic process. Iron and silica of the BIF were provided by the hydrothermal solutions emplaced at the vent sites situated at the Archean Mid-Oceanic Ridges. Variable Eu anomalies in the studied samples further indicate mixing of hydrothermal fluids at different temperatures with the bottom sea water, rather than variable admixture of felsic components. Due to thermal and chemical potential variation and upwelling, the iron and silica rich water was transported to the sites of deposition at the shallow shelf. Increased hydrothermal flux, and higher exit temperature appear responsible for bringing such large quantities of iron and silica into the oceans of Archean Singhbhum-Orissa basins. Non-existing Ce anomaly in the studied banded iron-formations attests to anoxic nature of the Archean bottom sea water.

Mineralogical study suggests that magnetite was the principal iron oxide mineral, now a relict phase whose depositional history is preserved in BHJ, where it remains in the form of martite. The platy hematite is mainly the product of martite. The different types of iron ores are intricately related with the BHJ. Hard laminated ores, martitegoethite ore and soft laminated ore are resultant of desilicification process through the action of hydrothermal fluids. Removal of silica from BIF and successive precipitation of iron by hydrothermal fluids of meteoric origin resulted in the formation of martite-goethite ore. The hard laminated ore has been formed in the second step of supergene processes, where the deep burial upgrades the hydrous iron oxides to hematite. Soft laminated ores and biscuity ore were formed where precipitation of iron was partial or absent. In this case, the leached out space remains with time and the ore becomes very fragile in between the laminae. Blue dust has been formed owing to circulating waters, which leached away the silica from protore. The presence of martite in massive ore along with their gradational contact of with BHJ suggests its syngenetic origin with BHJ. 


\section{Acknowledgements}

Financial assistance in the form of Council of Scientific and Industrial Research (CSIR, India) Ph.D. research fellowship to SR is gratefully acknowledged. We thank Prof. Somnath Dasgupta and the anonymous reviewer for the constructive and meticulous reviews on the earlier version of our paper.

\section{References}

Alchin D, Lickford V, Mienie P J, Nel D and Strydom M 2008 An integrated exploration approach to the Sishen South Iron Ore Deposit, Northern Cape Province, South Africa, and its implication for developing a structural and/or resource model for these deposits; Econ. Geol. (SEG Reviews) 15 317-338.

Alibert C and McCulloch M T 1993 Rare earth element and neodymium isotopic compositions of banded iron formations and associated shales from Hamersley, Western Australia; Geochim. Cosmochim. Acta $\mathbf{5 7}$ 187-204.

Banerji A K 1977 On the Precambrian banded ironformation and manganese ores of Singhbhum region, Eastern India; Econ. Geol. 72 90-98.

Barley M E, Pickard A L, Hagemann S G and Folkert S L 1999 Hydrothermal origin for the 2 billion year old Mount Tom Price giant iron ore deposit, Hamersley Province, Western Australia; Mineral. Depos. 34 784-789.

Barrett T J, Fralick P W and Jarvis I 1988 Rare-earthelement geochemistry of some Archean iron formations north of Lake Superior, Ontario; Can. J. Earth Sci. 25 $570-580$.

Beckwith R S and Reeve R 1969 Dissolution and deposition of monosilicic acid in suspensions of ground quartz; Geochim. Cosmochim. Acta. 23 745-750.

Beukes N J, Mukhopadhyay J and Gutzmer J 2008 Genesis of high-grade iron ores of the Archean Iron Ore Group around Noamundi, India; Econ. Geol. 103 365-386.

Beukes N J and Klein C 1990 Geochemistry and sedimentology of a facies transition from microbanded to granular iron formation in the early Proterozoic Transvaal Supergroup, South Africa; Precamb. Res. 47 99-139.

Beukes N J, Gutzmer J and Mukhopadhyay J 2003 The geology and genesis of high-grade hematite iron ore deposits; Applied Earth Sci. (Trans IMM, Sec. B) 112 18-25.

Beukes N J and Gutzmer J 2008 Origin and paleoenvironmental significance of major iron formations at the Archean-Paleoproterozoic boundary; Econ. Geol. (SEG Reviews) 15 5-47.

Bhattacharya H N, Chakraborty I and Ghosh K K 2007 Geochemistry of some banded iron formations of the Archean supracrustals, Jharkhand-Orissa region, India; J. Earth Syst. Sci. 116(3) 245-259.

Brown M C, Oliver N H S, Nicholas H S and Dickens G R 2004 Veins and hydrothermal fluid flow in the Mt. Whalesback Iron Ore district, eastern Hamersley Province, Western Australia; Precamb. Res. 128 441-474.

Brown P E 2008 Brief history of high-grade iron ore mining in North America (1848-2008); Econ. Geol. (SEG Reviews) 15 361-380.

Campbell A C, Palmer $M$ R, Klinkhammer G P, Bowers T S, Edmond J M, Lawrence J R, Casey J F, Thompson G, Humphris S, Rona P and Karson J A
1988 Chemistry of hot springs on the Mid-Atlantic Ridge; Nature 335 514-519.

Chakraborty K L and Majumder T 2002 Some important aspects of the banded iron formation (BIF) of eastern Indian shield (Jharkhand and Orissa); Indian J. Geol. 74(1-4) 37-47.

Clout J M F 2006 Iron formation-hosted iron ores in the Hamersley Province of Western Australia; Applied Earth Sci. (Trans IMM, Sec. B) 15(4) 115-125.

Cope I L, Wilkinson J J, Boyce A J, Chapman J B, Herrington R J and Rarris C J 2008 Genesis of the Pic de Fon Iron Oxide Deposit, Simandou range, Republic of Guinea, West Africa; Econ. Geol. (SEG Reviews) 15 339-360.

Dalstra H J and Rosierie 2008 Structural controls on high-grade iron ores hosted by Banded Iron Formation: A global perspective; Econ. Geol. (SEG Reviews) $\mathbf{1 5}$ 73-106.

Dalstra H J and Guedes S 2004 Giant hydrothermal hematite deposits with $\mathrm{Mg}$-Fe metasomatism: A comparison of the Carajás, Hamersley, and other iron ores; Econ. Geol. 99 1793-1800.

De Baar H J W, Bacon M P and Brewer P G 1985 Rare earth elements in the Pacific and Atlantic Oceans; Geochim. Cosmochim. Acta 49 1943-1959.

Derry L A and Jacobsen S B 1990 The chemical evolution of Precambrian seawater: Evidence from REEs in banded iron formations; Geochim. Cosmochim. Acta $\mathbf{5 4}$ 2965-2977.

Dunn J A 1935 The origin of iron ores in Singhbhum, India; Econ. Geol. 30 643-654.

Dymek R F and Klein C 1988 Chemistry, petrology and origin of banded iron formation lithologies from the $3800 \mathrm{Ma}$ Isua supracrustal belt, West Greenland; Precamb. Res. 39 247-302.

Eldertield H and Greaves M J 1982 The rare earth elements in sea water; Nature 296 214-219.

Figueiredo E Silva R C, Lobato L M, Rosiere C A, Hagemann S, Zucchetti M, Baars F J, Morais R and Andrade I 2008 A hydrothermal origin for the jaspiitehosted, giant Serra Norte iron ore deposits in the Carajas mineral province, Para State, Brazil; Econ. Geol. (SEG Reviews) 15 255-290.

Findlay D 1994 Diagenetic boudinage, an analogue model for the control on hematite enrichment iron ores of the Hamersley Iron Province of Western Australia, and a comparison with Krivoi Rog of Ukraine, and Nimba Range, Liberia; Ore Geol. Rev. 9 311-324.

Ghosh G and Mukhopadhyay J 2007 Reappraisal of the structure of the Western Iron Ore Group, Singhbhum craton, eastern India: Implications for the exploration of BIF-hosted iron ore deposits; Gondwana Res. 12 525-532.

Govett G J S 1966 Origin of banded iron-formation; Geol. Soc. Amer. Bull. 77 1191-1212.

Gross G A 1993 Industrial and genetic models for iron ore in iron formations; In: Mineral Deposit Modelling; Geol. Assoc. Canada, Spec. Paper 40 151-170.

Gruner J W 1937 Composition and structure of stilpnomelane; Am. Mineral. 22 912-925.

Gutzmer J and Beukes N J 1998 Earliest laterites possible evidence for terrestrial vegetation in the Proterozoic; Geology 26 263-266.

Gutzmer J, Chisonga B C, Beukes N J and Mukhopadhyay J 2008 The geochemistry of Banded Iron Formation-hosted high-grade hematite-martite ores; Econ. Geol. (SEG Reviews) 15 157-183.

Hagemann S G, Barley M E, Folkert S L, Yardley B W and Banks D A 1999 A hydrothermal origin for the 
giant Tom Price iron ore deposit; In: Mineral Deposits, Processes to Processing (eds) Stanley C J et al (Rotterdam: A A Balkema) pp. 41-44.

Hagemann S H, Rosiere C A, Lobato L, Baars F, Zucchetti M and Figueiredo E Silva R C 2006 Controversy in genetic models for Proterozoic high-grade, banded iron formation (BIF) - related iron deposits unifying or discrete model(s); Appl. Earth Sci. (Trans. Inst. Min. Metall. B) 115(4) 147-151.

Harmsworth R A, Kneeshaw M, Morris R C, Robinson C J and Shrivastava P K 1990 BIF-derived iron ores of the Hamersley Province; In: Geology of the Mineral Deposits of Australia and Papua New Guinea (ed.) Hughes F E, Aus IMM. Mono., Melbourne 14 617-642.

Holland H D 1973 The oceans: A possible source of iron in iron-formation; Econ. Geol. 68 1169-1172.

Jones H C 1934 The iron ore deposits of Bihar and Orissa; Geol. Surv. India Memoir 63 1098-1109.

Kato Y, Kawakami T, Kano T, Kunugiza K and Swamy N S 1996 Rare-earth element geochemistry of banded iron formations and associated amphibolite from the Sargur belt, south India; J. Southeast Asian Earth Sci. 14(3/4) 161-164.

Kato Y, Ohta I, Tsunematsu T, Watanabe Y, Isozaki Y, Maruyama S and Imai N 1998 Rare earth element variations in mid-Archean banded iron formations: Implications for the chemistry of ocean and continent and plate tectonics; Geochim. Cosmochim. Acta 62(21/22) 3475-3497.

Khan R M K, Sharma S D, Patil D J and Naqvi S M 1996 Trace, rare-earth element, and oxygen isotopic systematics for the genesis of banded iron formations: Evidence from Kushtagi schist belt, Archaean Dharwar Craton, India; Geochim. Cosmochim. Acta 60(17) 3285-3294.

Klein C and Beukes N J 1989 Geochemistry and sedimentology of a facies transition from limestone to ironformation deposition in the Early Proterozoic Transvaal Supergroup, South Africa; Econ. Geol. 84 1733-1774.

Lepp H and Goldich S S 1964 Origin of the Precambrian iron-formation; Econ. Geol. 69 1025-1060.

Lobato L M, Figueiredo E Silva R C, Hagemann S, Thorne W and Zucchetti M 2008 Hypogene alteration associated with high-grade banded iron formation-related iron ore; Econ. Geol. (SEG Reviews) 15 107-128.

MacLean W H and Kranidiotis P 1987 Immobile elements as monitors of mass transfer in hydrothermal alteration: Phelps Dodge massive sulfide deposit, Matagami; Quebec. Geol. 82 951-962.

Majumder T 1985 Environment and Petrogenesis of the Precambrian Banded Iron Formation of the iron ore group, eastern India; Bull. Geol. Surv. Finland 331 201-213.

Manikyamba C, Balaram V and Naqvi S M 1993 Geochemical signatures of polygenecity of Banded Iron Formations of the Archean Sandur greenstone belt (schist belt), Kamataka Nucleus, India; Precamb. Res. 61 137-164.

Martin D M, Li Z X, Nemchin A A and Powell C M 1998 A pre- $2.2 \mathrm{Ga}$ age for giant hematite ores of the Hamersley Province, Australia; Econ. Geol. 93 1084-1090.

McLellan J G and Oliver H S 2008 Application of numerical modeling to extension, heat and fluid flow in the genesis of giant Banded Iron Formation-hosted hematite ore deposits; Econ. Geol. (SEG Reviews) 15 185-196.

McLellan J G, Oliver N H S and Schaubs P M 2004 Fluid flow in extentional environments; numerical, modelling with an application to Hamersely iron ores; J. Struct. Geol. 26 1157-1171.
Michard A and Albarede F 1986 The REE content of some hydrothermal fluids; Chem. Geol. 55 51-60.

Morris R C 1985 Genesis of iron ore in banded iron formation by supergene and supergene-metamorphic processes, a conceptual model; In: Handbook of Strata-Bound and Stratiform Ore Deposits (ed.) Wolf K H (Amsterdam: Elsevier) 13 73-235.

Morris R C and Horwitz R C 1983 The origin of the ironformation-rich Hamersley Group of Western Australia deposition on a platform; Precamb. Res. 21 273-297.

Mukhopadhyay J, Gutzmer J, Beukes N J and Bhattacharya H N 2008 Geology and genesis of the major Banded Iron Formation-hosted high grade iron ore deposits of India; Econ. Geol. (SEG Reviews) 15 291-316.

Murthy V N and Acharya S 1975 Lithostratigraphy of the Precambrian rocks around Koira, Sundargarh Dt. Orissa; J. Geol. Soc. India 16 55-68.

Oliver N H S and Dickens G R 1999 Hematite ores of Australia formed by syntectonic heated meteoric fluids; In: Mineral Deposits, Processes to Processing (eds) Stanley C J et al (Rotterdam: Balkema) pp. 889-892.

Otake T, Wesolowski D J, Anovitz L M, Allard L F and Ohmoto H 2007 Experimental evidence for non-redox transformations between magnetite and hematite under $\mathrm{H}_{2}$-rich hydrothermal conditions; Earth Planet. Sci. Lett. 257(1-2) 60-70.

Pirajno F and Bagas L 2008 A review of Australia's Proterozoic mineral systems and genetic models; Precamb. Res. 166(1-4) 54-80.

Polat A and Frei R 2005 The origin of early Archean banded iron formations and of continental crust, Isua, southern West Greenland; Precamb. Res. 138 151-175.

Powell C M A, Oliver N H, Li Z X, Martin D M B and Ronaszeki J 1999 Synorogenic hydrothermal origin for giant Hamersley iron oxide ore bodies; Geology $\mathbf{2 7}$ $175-178$

Ramanaidou E, Wellsm M, Belton D, Verrall M and Ryan C 2008 Mineralogical and microchemical methods for the characterization of high-grade banded iron formationderived iron ore; Econ. Geol. (SEG Reviews) $\mathbf{1 5}$ $129-156$.

Rao T G and Naqvi S M 1995 Geochemistry, depositional environment and tectonic setting of the BIF's of the Late Geochemistry of BIF of Jharkhand-Orissa, India 259 Archaean Chitradurga Schist Belt, India; Chem. Geol. $121217-243$.

Rasmussen B, Fletcher I R, Muhling J R, Thorne W S and Broadbent G C 2007 Prolonged history of episodic fluid flow in giant hematite ore bodies: Evidence from in situ $\mathrm{U}-\mathrm{Pb}$ geochronology of hydrothermal xenotime; Earth Planet. Sci. Lett. 258(1-2) 249-259.

Rosiere C A and Rios F J 2004 The origin of hematite in high-grade iron ores based on infrared microscopy and fluid inclusion studies: The example of the Conceicao mine, Quadrilatero Ferrifero, Brazil; Econ. Geol. 99 $611-624$.

Rosiere C A, Baars F J, Seoane J C S, Lobato L M, da Silva L L, de Souza S R and Mendes G E 2006 Structure and iron mineralization of the Caraja Province; Applied Earth Sci. (Trans. Inst. Min. Metall. B) 115(4) 126-133.

Saha A K 1994 Crustal evolution of Singhbhum, North Orissa, Eastern India; Geol. Soc. India Memoir $\mathbf{2 7}$ 341.

Saha A K, Ghosh S, Dasgupta D, Mukhopadhyay K and Ray S L 1984 Studies on crustal evolution of the Singhbhum Orissa Iron Ore Craton. Monograph on Crustal Evolution; Indian Soc. Earth Sci. 1-74. 
Sarangi S K and Acharya S 1975 Stratigraphy of the iron ore group around Khandadhar, Sundargarh district, Orissa; Indian J. Earth Sci. 2 182-189.

Sarkar S N, Saha A K and Miller J A 1969 Geochronology of the Precambrian rocks of Singhbhum and adjacent region, Eastern India; Geol. Mag. 106 13-45.

Taylor D, Dalstra H J, Harding A E, Broadbent G C and Barley M E 2001 Genesis of high grade hematite ore bodies of the Hamersley Province, Western Australia; Econ. Geol. 96 837-873.

Thorne W S, Hagemann S G and Barley M 2004 Petrographic and geochemical evidence for the hydrothermal evolution of the North Deposit, Mt. Tom Price, Western Australia; Mineral. Depos. 39 766-783.

Thorne W, Hagemann S, Webb A and Clout J 2008 Banded Iron Formation-related iron ore deposits of the Hamersley Province, Western Australia; Econ. Geol. (SEG Reviews) 15 197-221.

van Schalkwyk J and Beukes N J 1986 The Sishen iron ore deposit, Griqualand West; In: Mineral deposits of
Southern Africa (eds) Annhaeusser C R and Maske S S, Geological Society of South Africa, Johannesburg, 931-956.

Webb A and Clout J 2008 Banded Iron Formation-Related Iron Ore Deposits of the Hamersley Province, Western Australia; Econ. Geol. (SEG Reviews) 15 197-221.

Webb A D, Dickens G R and Olivers N H H 2004 Carbonate alteration of the upper Mount McRae shale beneath the martite-macroplaty hematite ore deposit at Mount Whaleback, Western Australia; Mineral. Depos. 39 632-645.

Webb A, Dickens G and Oliver N H S 2003 From banded iron-formation to iron ore: Geochemical and mineralogical constraints from across the Hamersley Province, Western Australia; Chem. Geol. 197 215-251.

Zahida Begum, Balaram V, Ahmad S M, Satyanarayanan M and Rao T G 2007 Determination of trace and rare earth elements in marine sediment reference naterials by ICP-MS: Comparison of open and closed acid digestion methods; Atomic Spectroscopy 28(2) 41-50. 